\title{
وظائف الإعلام الثقافي في عصر العولمة
}

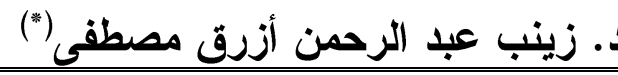

\section{المستنفلم}

تستمد هذه الدراسة أهميتها من منظور اتصالى ذلك أن الهويات الثقافيــة

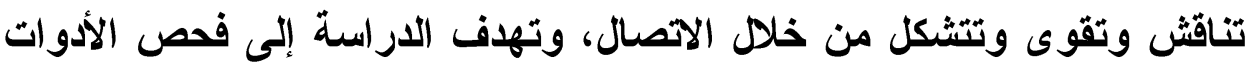

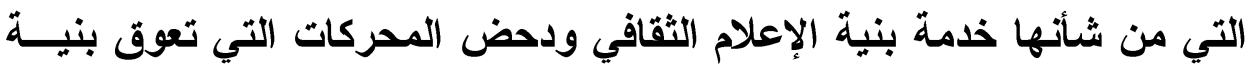

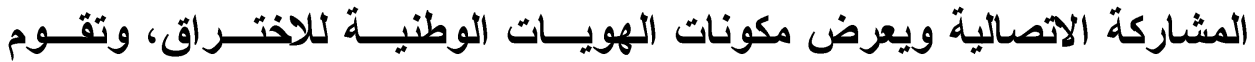

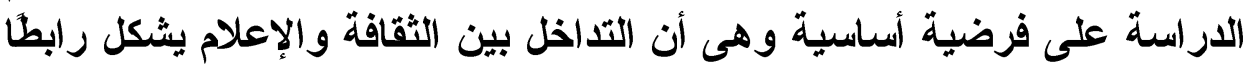

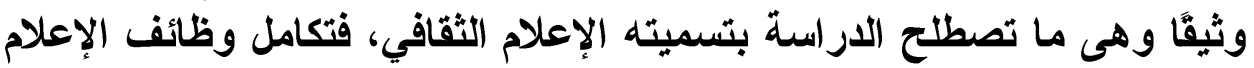

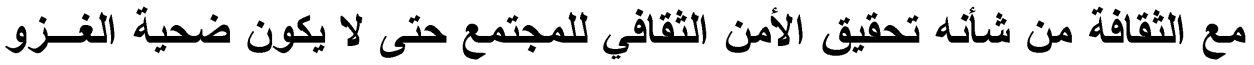

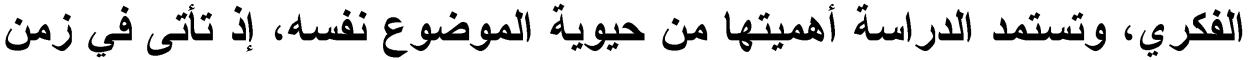

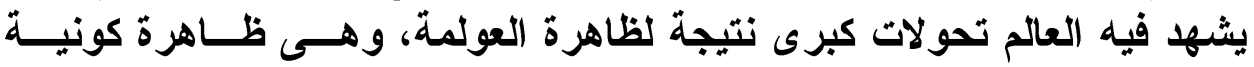

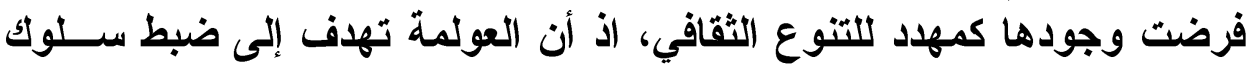

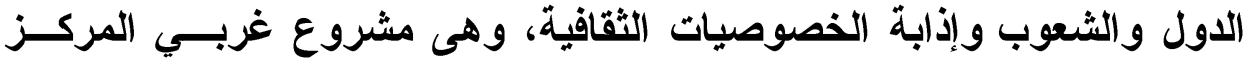

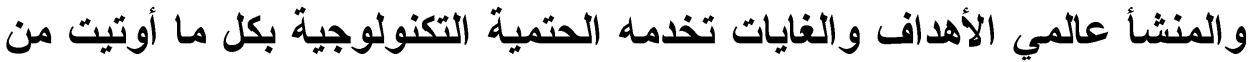

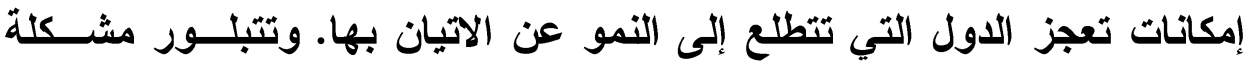

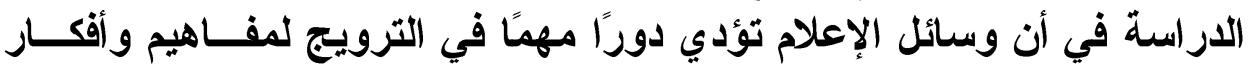

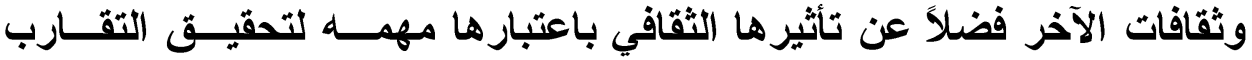

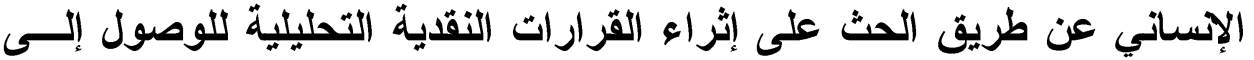

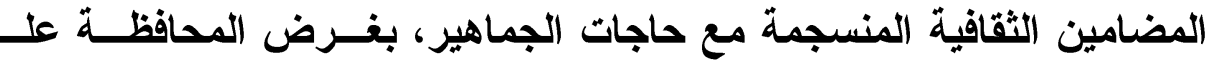

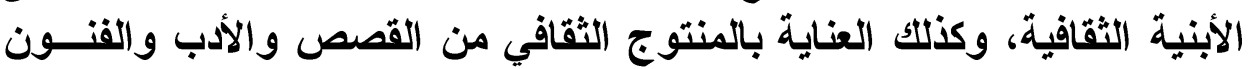
وغيرها ـ من خلال ثلاثة مباحث المبحث الأول يناقش (مفهوم الإعلام الثقافي ) كاستهلال مهم للار اسة هن ـ اما المبحث الثاني فيشير إلى (مفهوم العولمة كمهدد للأتيات الثقافية للاول) ويقترح المبحث الثالث( الوظائف التي يمكن أن يحققها

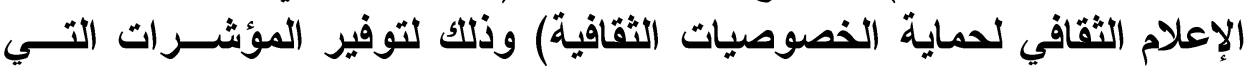

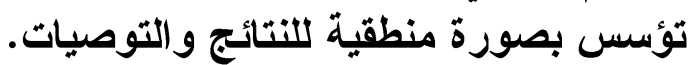
الكلمات المفتاحية : الإعلام، الثقافة، الإعلة الإعلام الثقافي، العولمة . 


\section{Abstract}

The importance of this study comes out from a communicative perspective, that the cultural identities are discussed, strengthened and formed through communication. The study aims to investigate tools that serve the cultural media structure and refute the challenges that impede the structure of communication and expose the components of national identities for penetration. The study basic hypothesis depend on The overlap between culture and media is a close link, which the study concept to call it cultural media, integration of the functions of media with culture lead to cultural security of the community, so as not to be the victim of intellectual invasion, the study derives its importance from the vitality of the subject itself, where it comes in a time when the world is undergoing major transformations as a result of the phenomenon of globalization, which is a global phenomenon imposed its existence as a threat of cultural diversity, as Globalization is aimed at controlling the behavior of states and peoples and eroding cultural specificities. It is a Western roots and establishes project, and global goals. It is served by technological determinism with all the potential that the countries aspire to growth cannot achieve. The problem of the study is concentrate on that the media play an important role in promoting the concepts, ideas and cultures of the other, as well as their influence on the cultural as a mission to achieve human rapprochement by stimulating the enrichment of analytical critical decisions to 
reach the cultural contents consistent with the needs of the community, in order to keep the cultural product, literature, arts and others. Through three topics, the first topic discusses (the concept of cultural media) as an important reflection of the study. The second topic refers to "the concept of globalization as a threat to the cultural identities of countries" and the third topic proposes (the functions that cultural media can achieve to protect cultural specificities) in order to provide indicators that logically establish the results and recommendations.

Keywords: Media, Culture, Cultural Media, Globalization. 


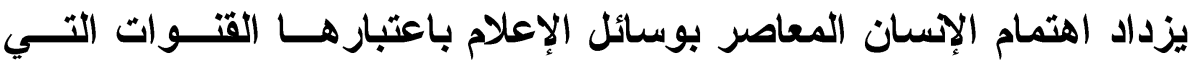

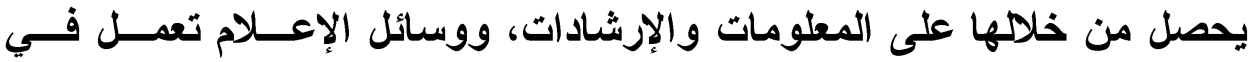
مواقف معدة لها من قبل العملية الاجتماعية. إضافة إلى أن الإنسان بطبعه كائن

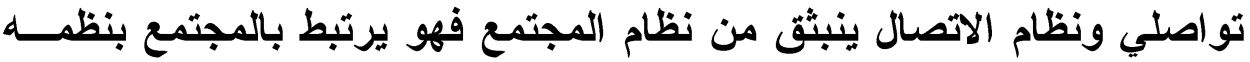

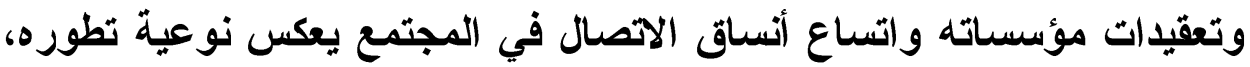

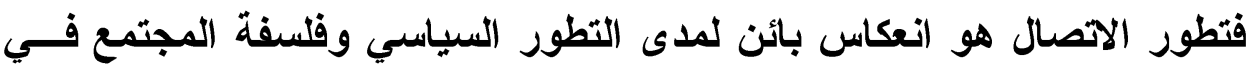

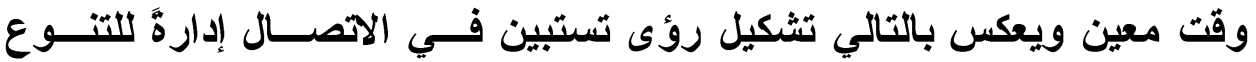

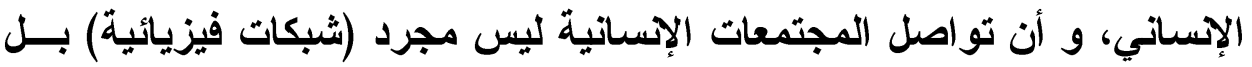
غدا أسـاسًا لأيديولوجيا التقدم. وقد اسنتُوحِيَت التصورات الأولى لعلم الاتصــال

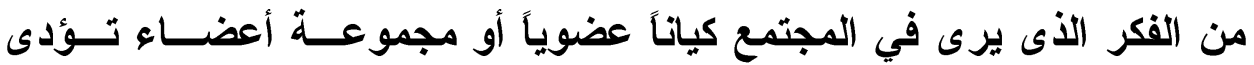

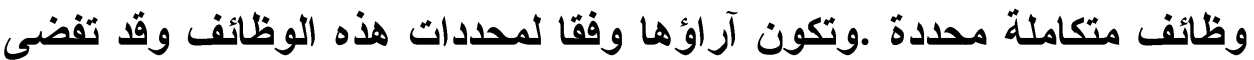

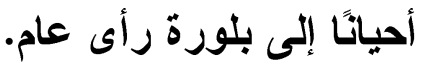

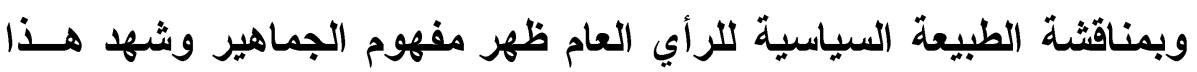

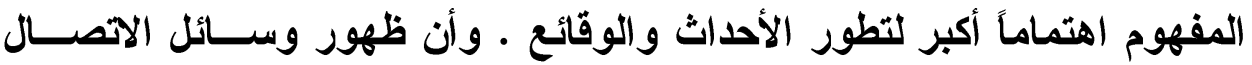

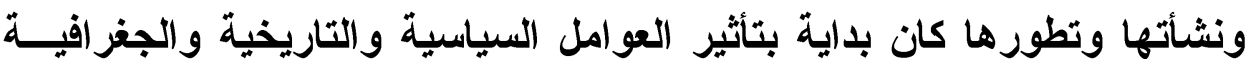

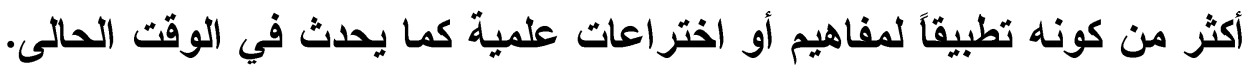

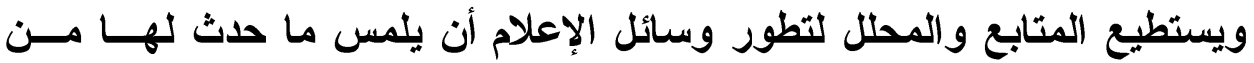
تغير ات.

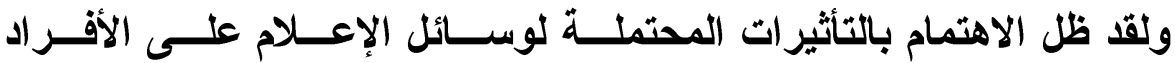

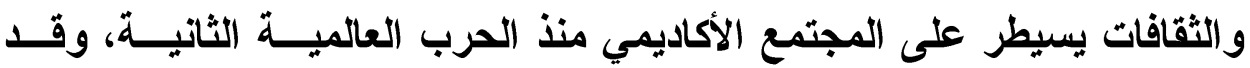

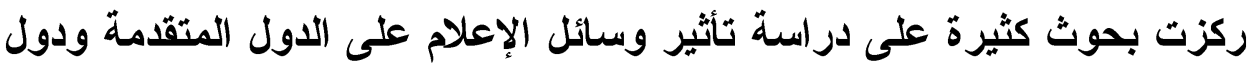

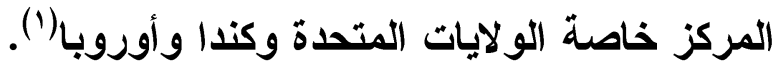

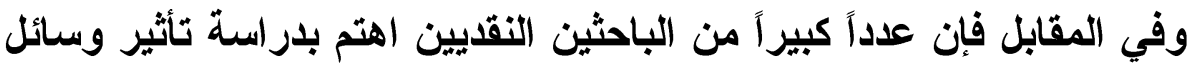

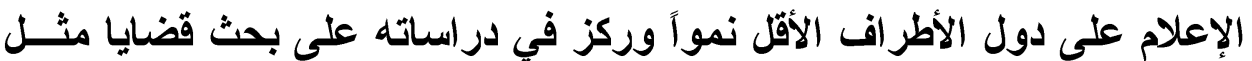
القوة والسيطرة والحتمية الاقتصادية والعوامل الأخرى المتصلة بها. على الرغم من أن نظرية الاستعمار الثقافي كاتت تتمتع بمصداقية الإية باعتبار ها

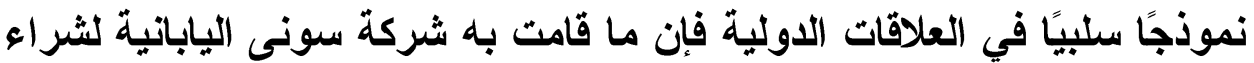


شركة كولومبيا للإنتاج السينمائي الأمريكية، أجبر الباحثين على إعادة التفكير

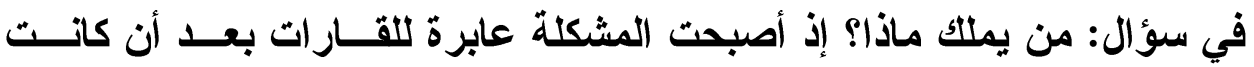

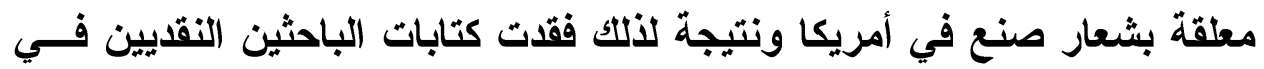

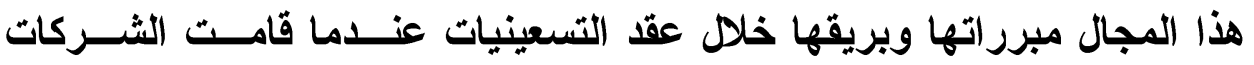

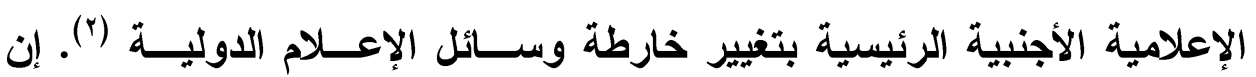

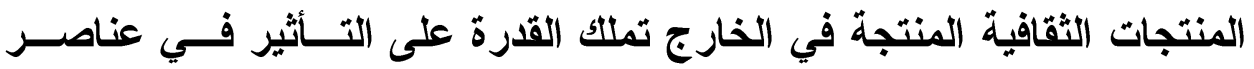

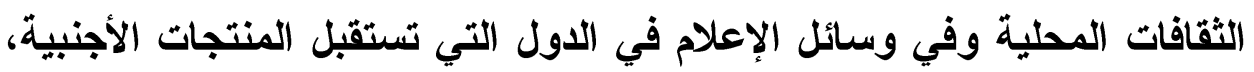

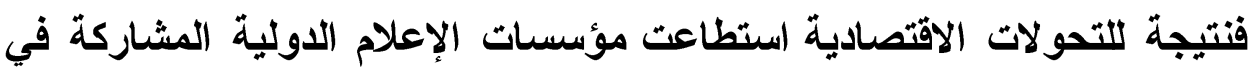

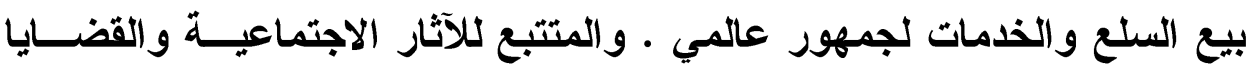

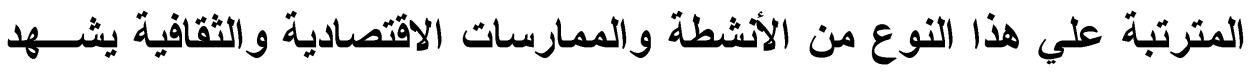

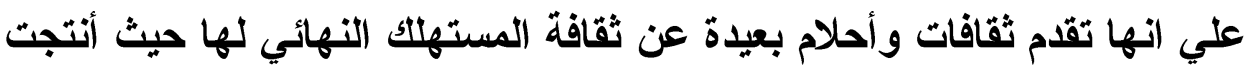

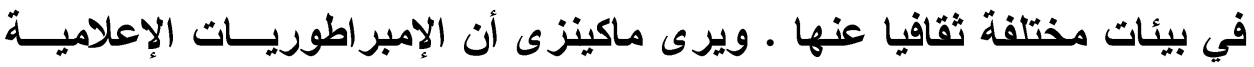

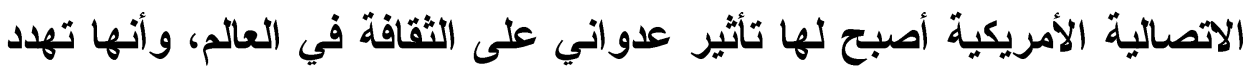

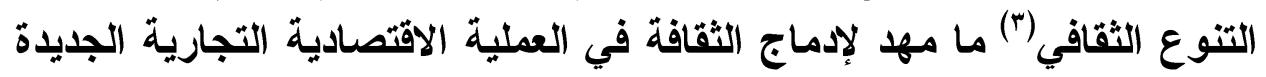

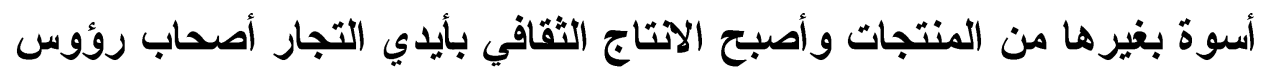

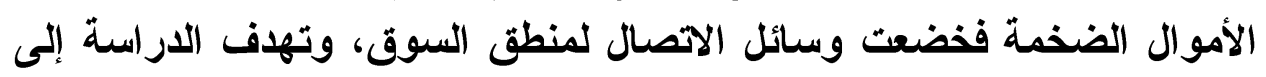

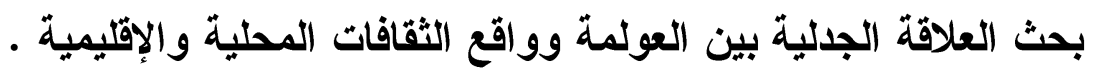

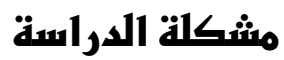

ومهما اختلفت الآراء وتباينت حول من يملك السيطرة الأكبر علــى البيئــة

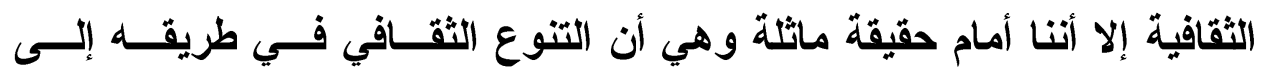

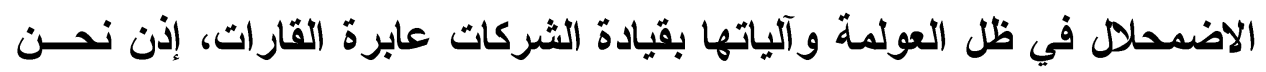

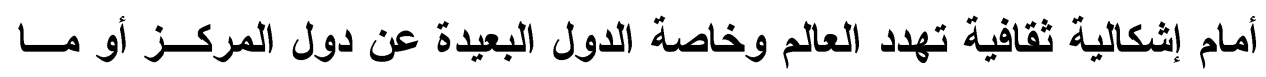

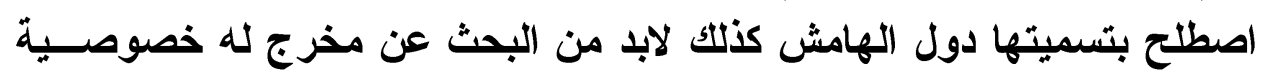

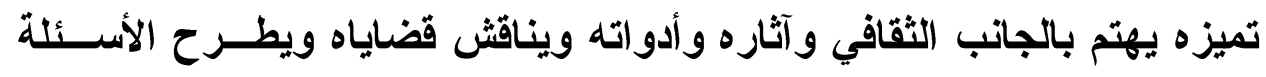

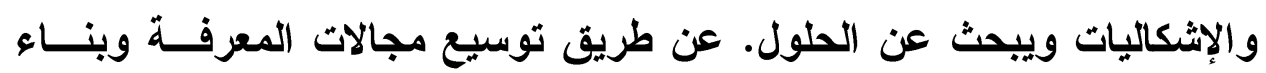

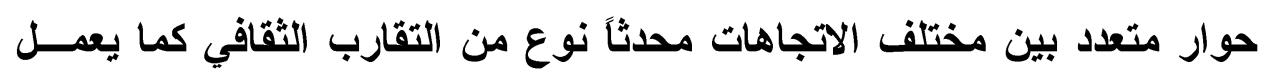

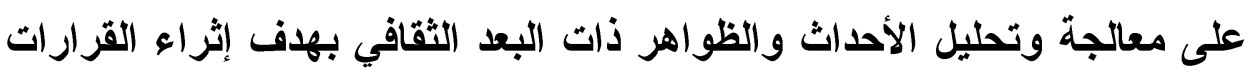

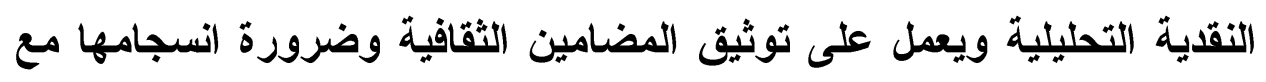


حاجات الجمهور بغرض المحافظة على أبنية الثقافة الوطنية وصسـون الــات

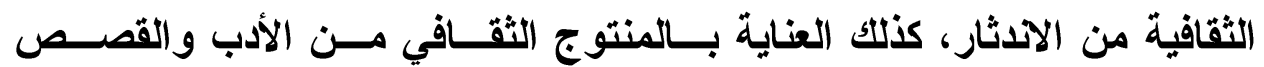

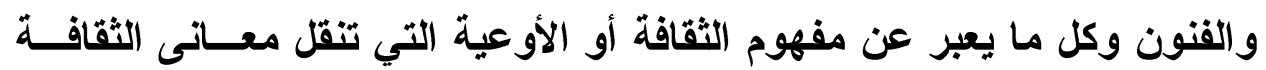
و الترويج لكل ذلك من خلال وسائل الإعلام .

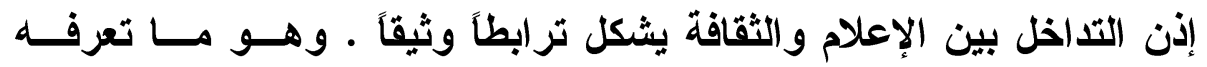

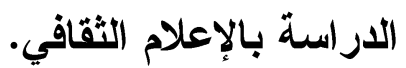
وتتكامل الثقافة مع وظائف الإعلام التي من شأنها ضمان الأمن الثقـــافي للمجتمع حتى لا يكون ضحية الغزو الفكري •

\section{فرضية الدراسة:}

لا يختلف اثنان في أن الإعلام يعتبر أحد الأســلحة الإســتراتيجية البالغــة

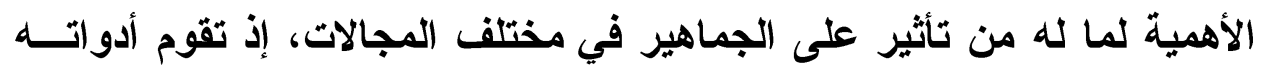

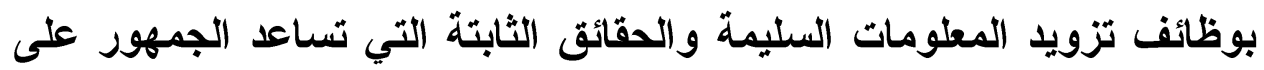

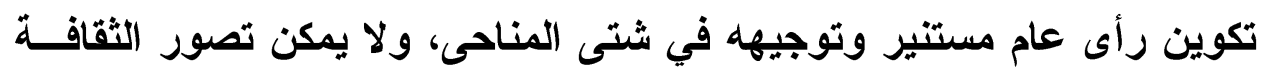

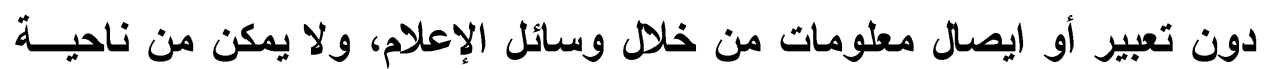

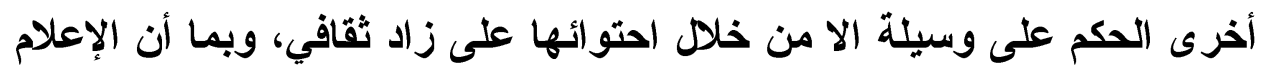

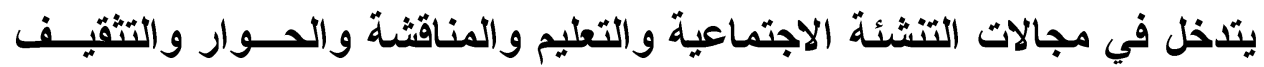

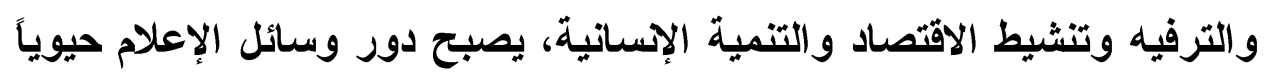

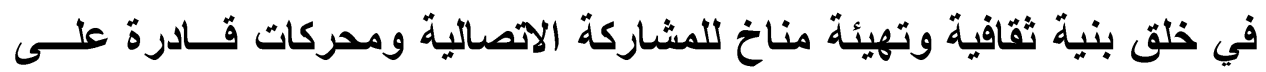

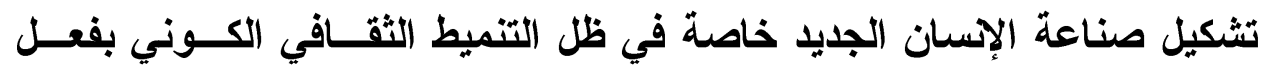

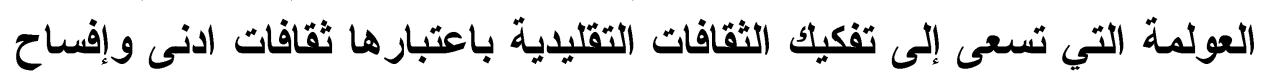

$$
\text { الجبال لهيمنة ثقافة أحادية. }
$$

- يسهم الإعلام في تكوين اتجاهات ايجابية داخل المجتمعات ويفجر الطاقات

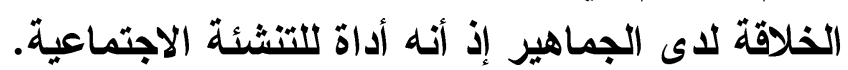

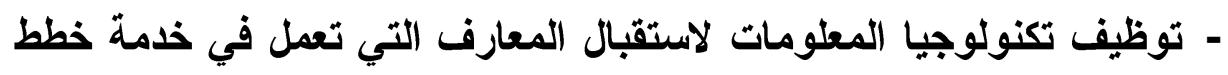

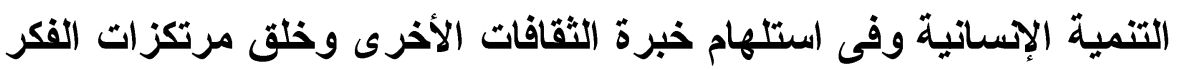


- تعمل القنوات الفضائية التجارية المملوكة للثركات الكبرى على تحويـل

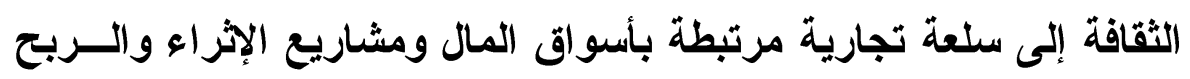

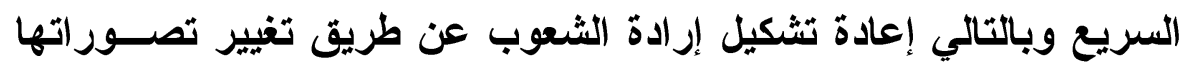

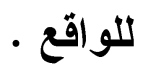
- التنميط الثقافي الربحي أدى إلى سيادة ثقافة جماهيرية متدنية .

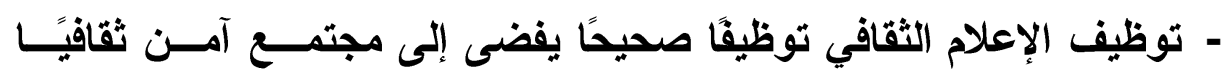

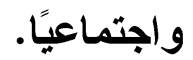

\section{أهمية الدراسة:}

وتتميز هذه الاراسة بخاصية مهمة تكتسب هذه الأهمية وفقا لعدة أوجه:

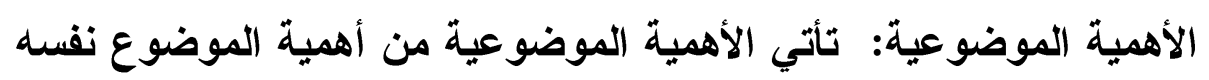

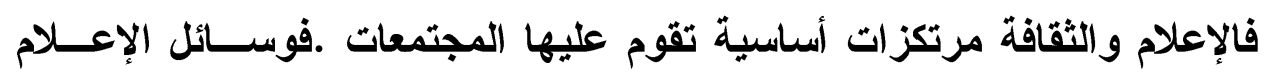

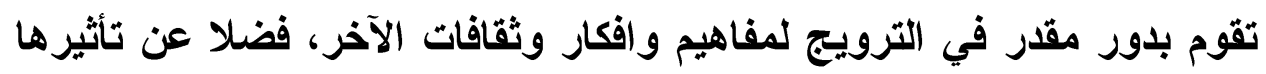

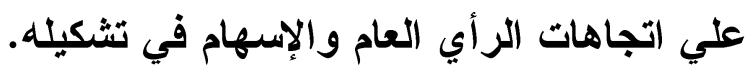

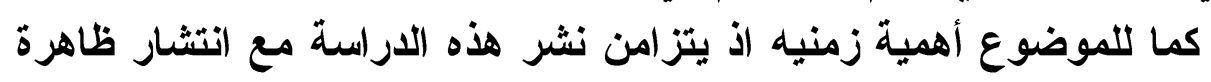

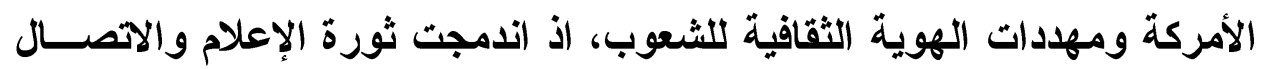

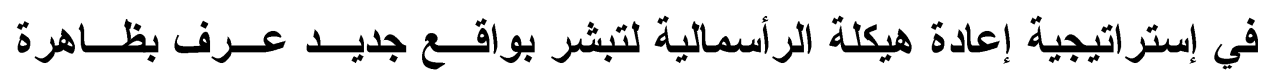

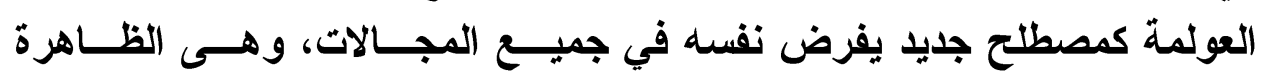

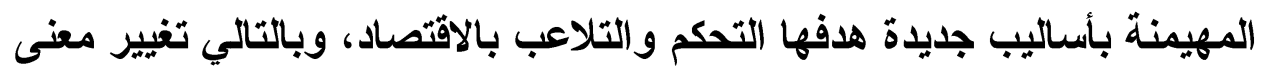

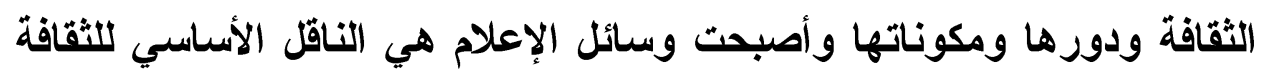

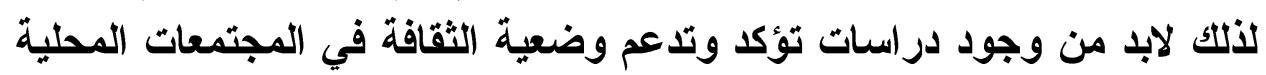

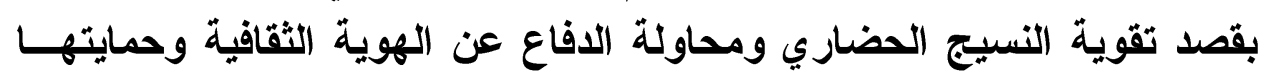

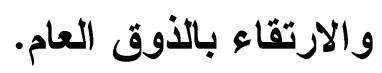


مجلة كلية الآداب، جامعة سوهاج، العدد الخمسون، الجزء الأول، يناير 9 أ Y م

$=$

أهداف الدراستة

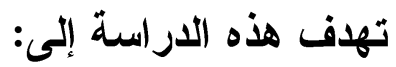

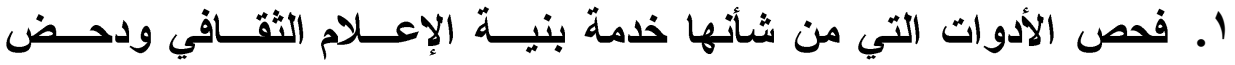

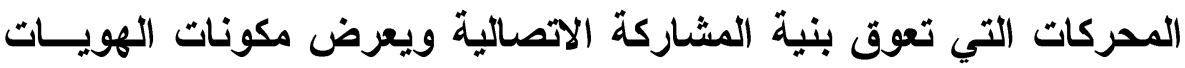

الوطنية لناختر اق.

r. إبراز وظائف الثقافة وأدواتها ومالها من أهمية في الحفــاظ علــى الـــات

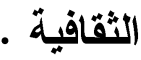

r. التركيز على أهمية المحتوى الثقافي وضرورة الارتقاء به في وقت ساد فيه

تسليع الثقافة.

ع. تبيين الوظائف الفتية والجمالية والعلمية والاجتماعية من خلال إدراك قيمة

الفكر و الفن و الأوق. 


\section{المبحث الأول}

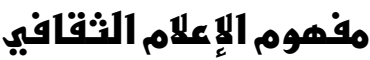

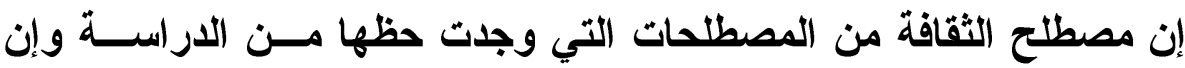
اختلفت حولها الالالات إلا أن معظمها يشير إلى كل ما أنتجه البشر من أفهــار

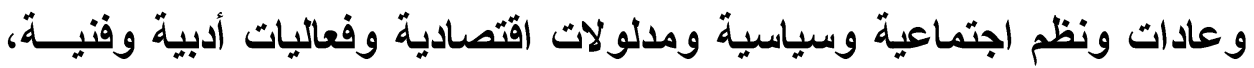

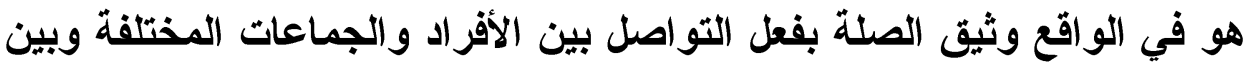

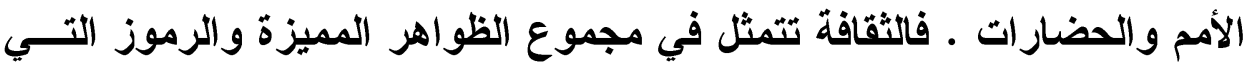

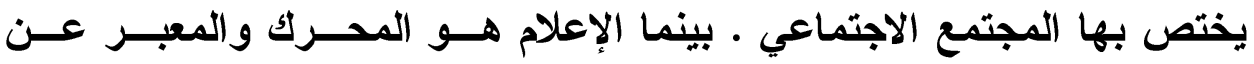

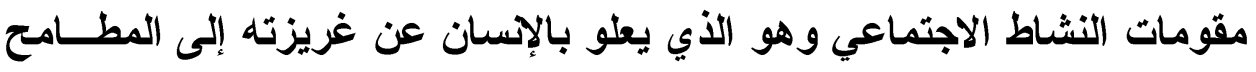

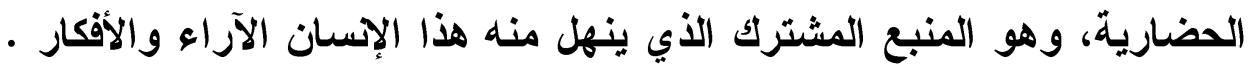

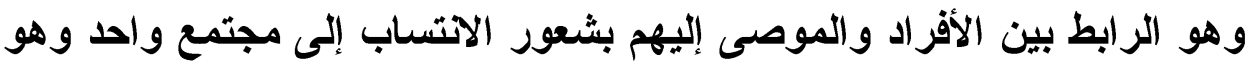

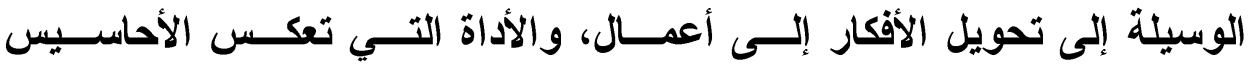

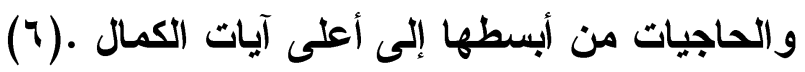

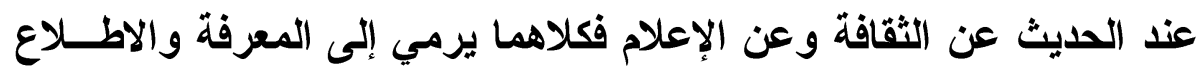

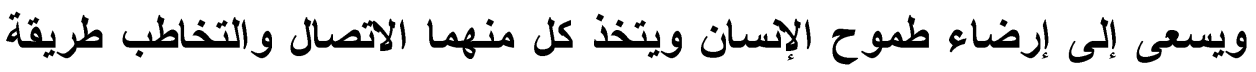

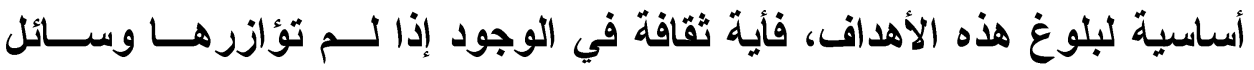

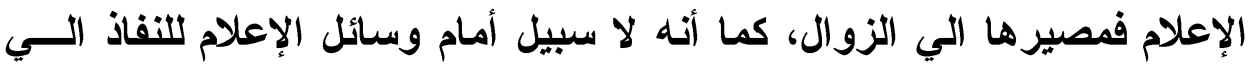

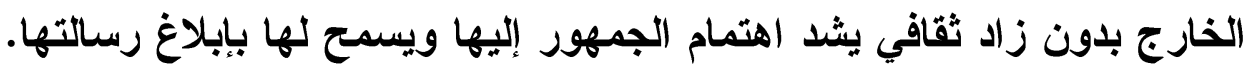

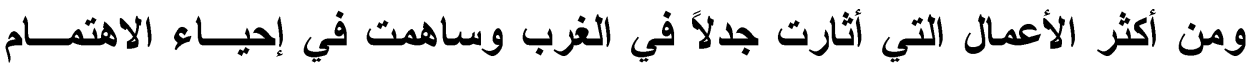

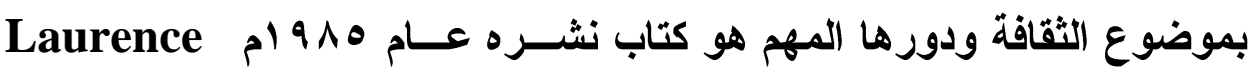
Hinson $\{$ Under development is a state of Mind\} The Latin American Case

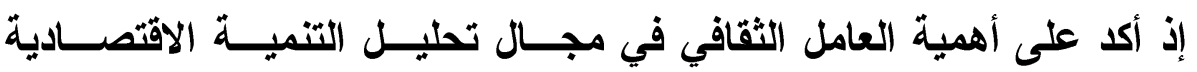

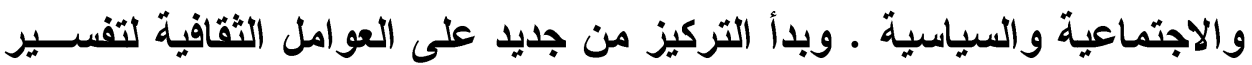

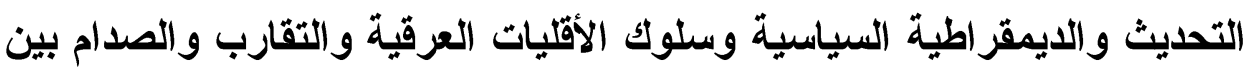

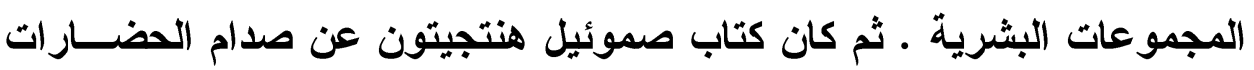

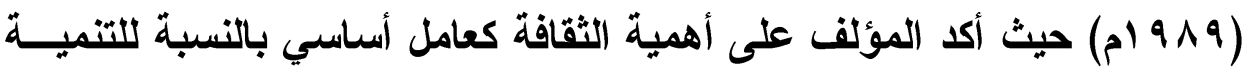


و الصدام بين الجماعات البشرية، اذ أن الصدام في العالم الجديد في نظره سوف

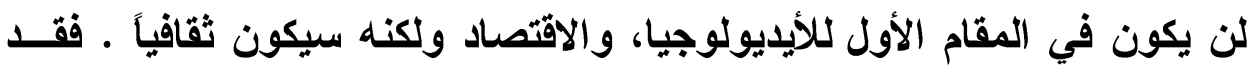

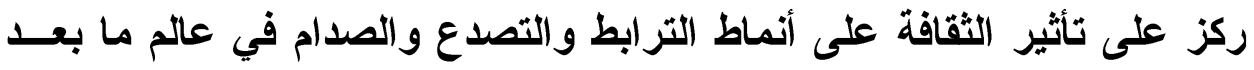

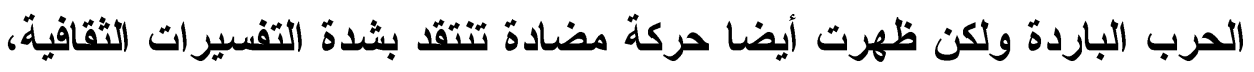

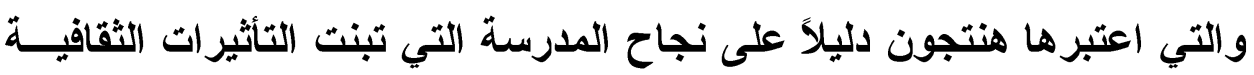

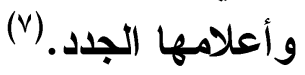

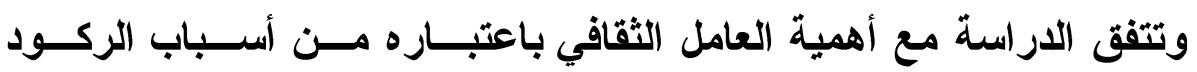

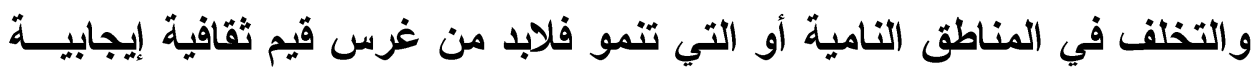

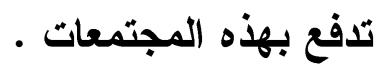

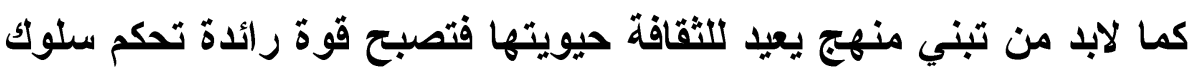

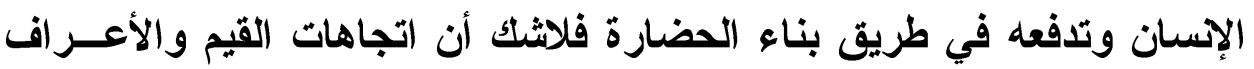

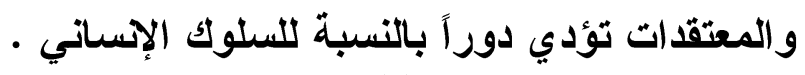

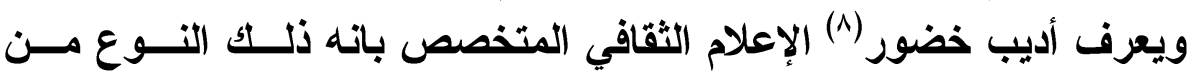

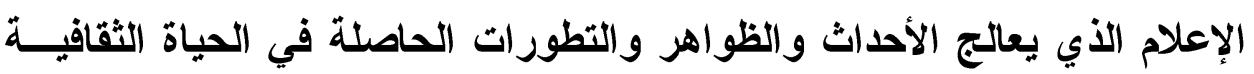
ويتوجه أساساً إلى جمهور نوعى معنى مهتم بالثأن الثقافي، ويظهر الإعـلام

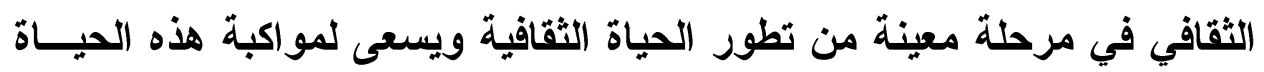

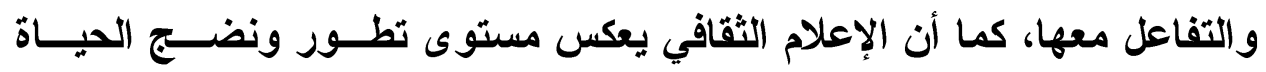

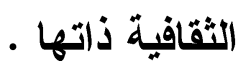

غير أن هذا التعريف يقتصر علي الإعلام الثقافي المتخصص ولعله يقصـــ

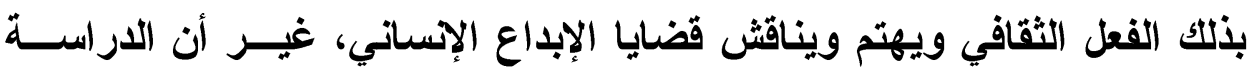

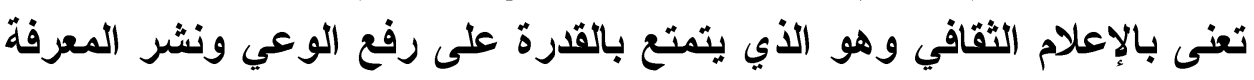

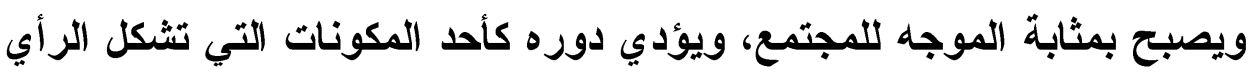

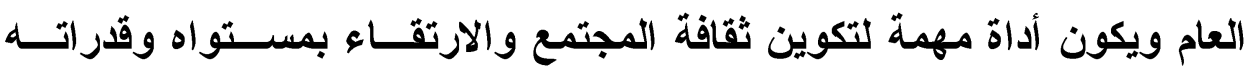

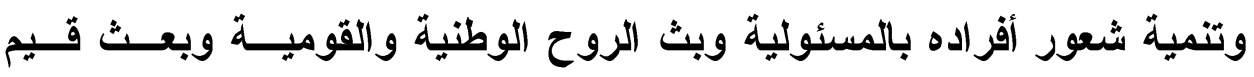

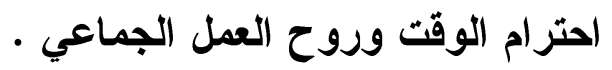

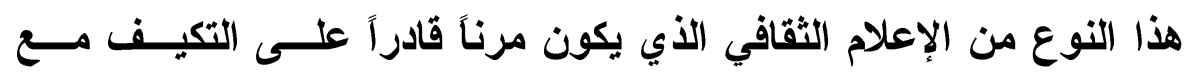

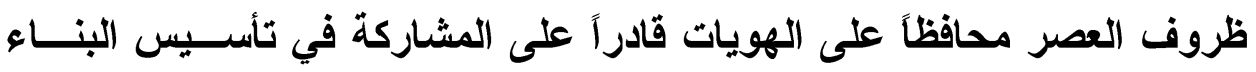

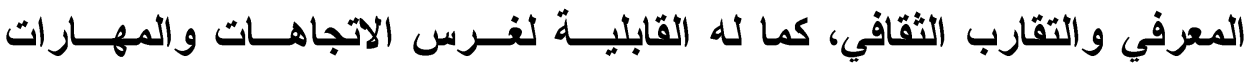


و المحافظة على الأبنية القيمية في مواجهة شتى المتغيرات التي تحملها ريــاح العولمة . مالفي

كنلك تعنى الاراسة بالإشارة إلى الدور الذى يمكن أن يضطلع به الإعـلام

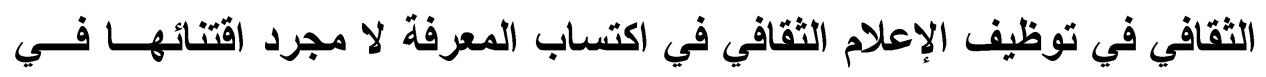

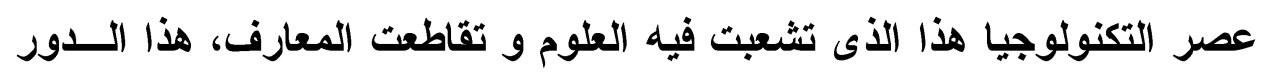

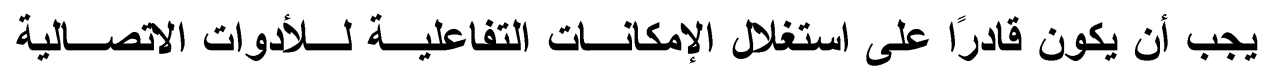

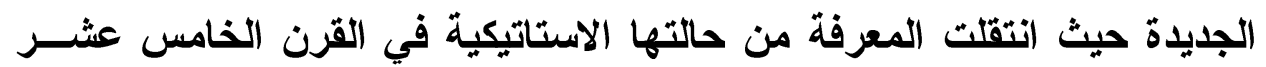

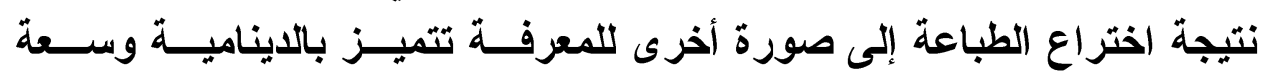
الانتشار فاتسمت بالجماهيرية.

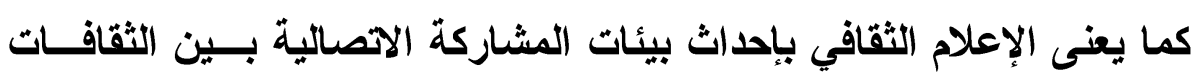

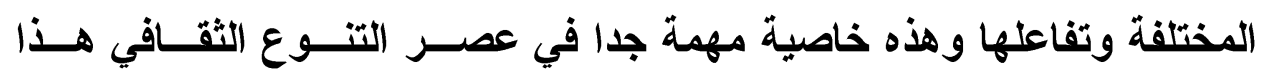
ومحاولة الحفاظ على الهويات الوطنية. 


\section{المبــث النانبي \\ 1الإعلام النثقافي والعولمة}

يناقش هذا المبحث الإعلام الثقافي والعولمة لما لهذا الدور من أهمية فـي

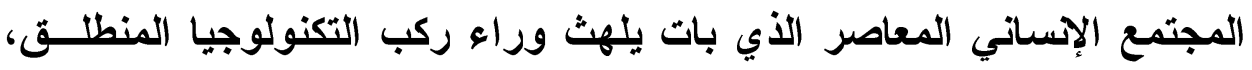

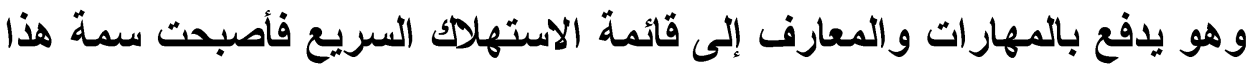

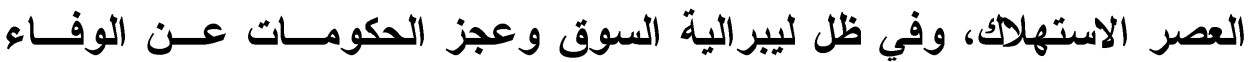

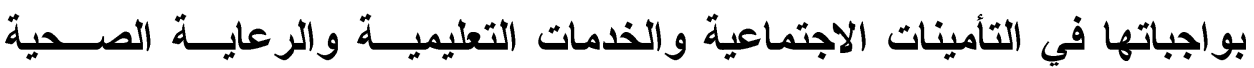

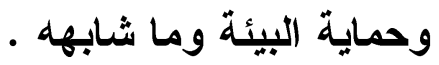

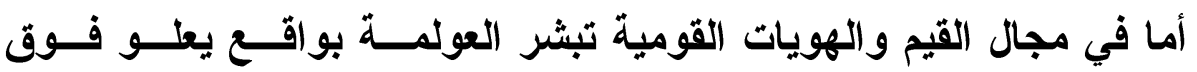

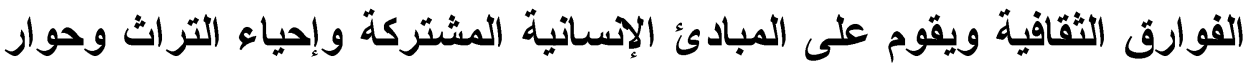

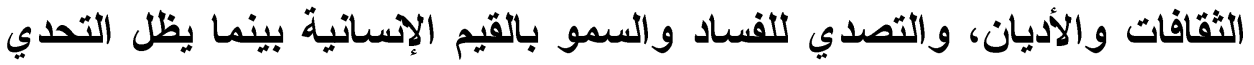

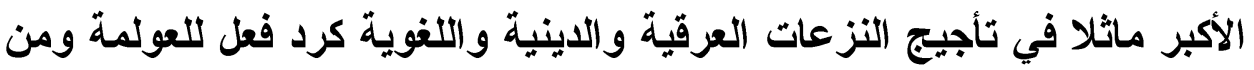

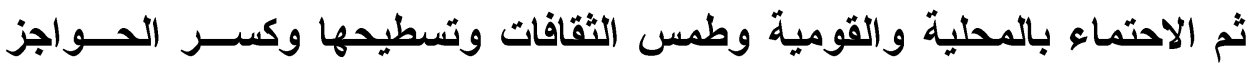
اللغوية مع دعم اللغات القومية. كما أن عولمة الإعلام تعتبر من المخاطر التي يمكن أن تطيح بالاســثقلالية

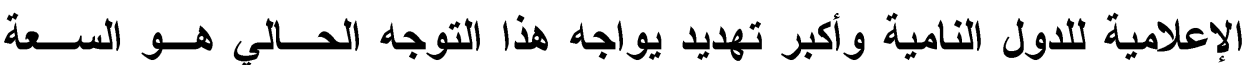

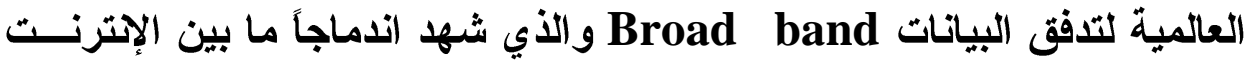
والتلفزيون والهواتف النقالة ما يعني مزيد من الغزو الإعلامي الغربي وسيادة

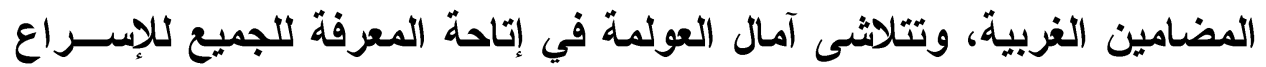
في معدلات التنمية من خلال خصخصة قطاع الاتصالات وتوسيع نطاقه و وإقامة

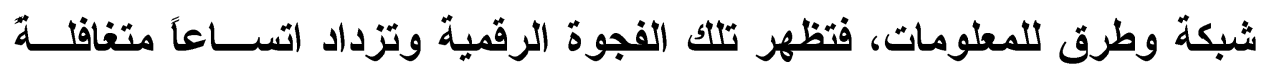

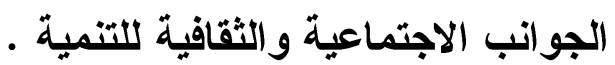

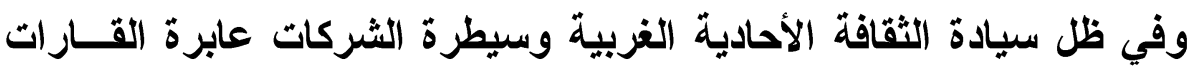

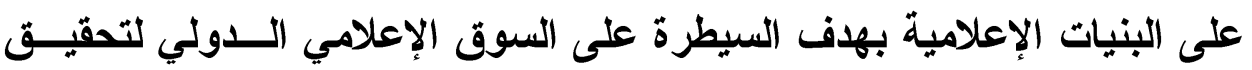

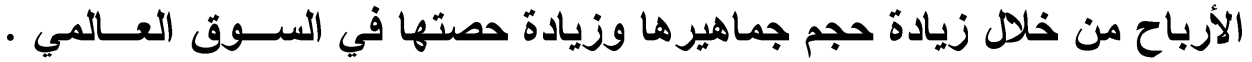

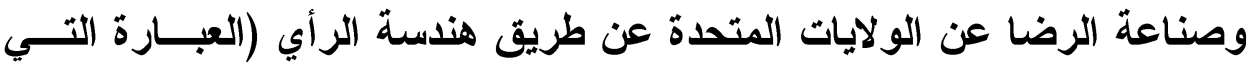

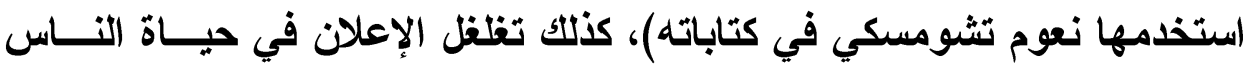


مما يجعل الثقافة ذاتها وأفعالها سلعة تباع وتثترى. ثم تأتى الســمة الأكثر

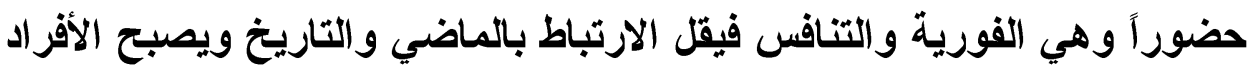

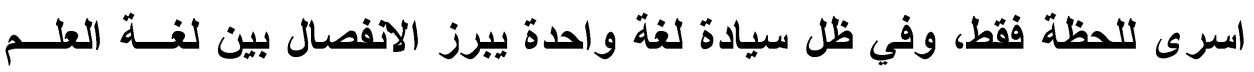

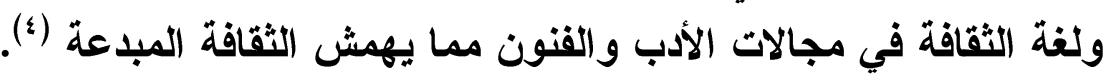

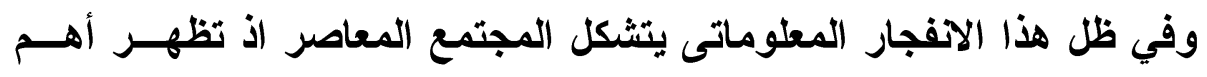

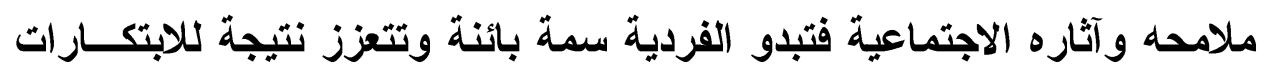

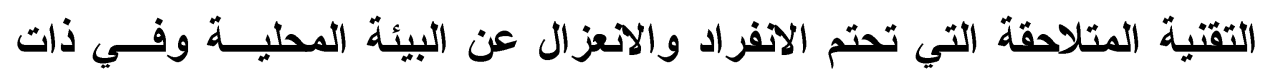

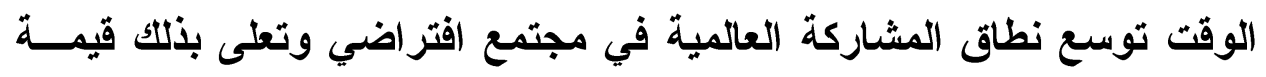

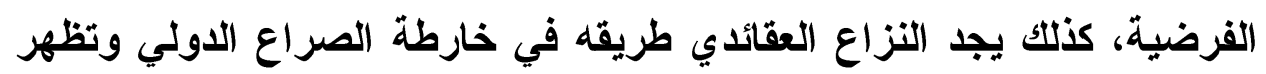

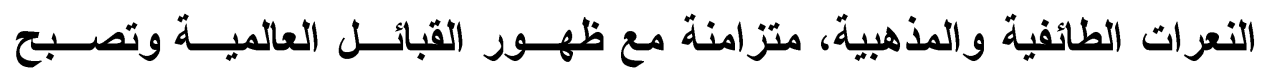

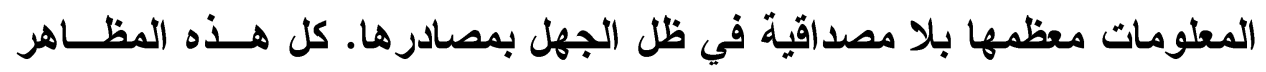

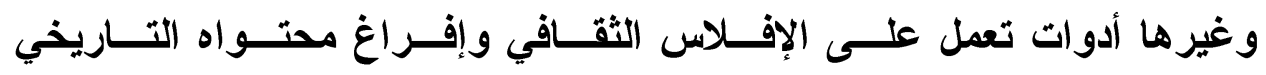

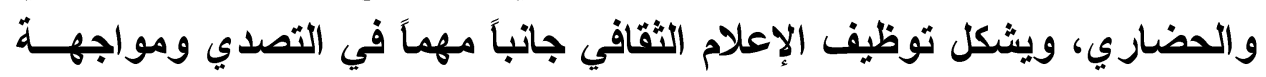
هذه الإثكاليات .

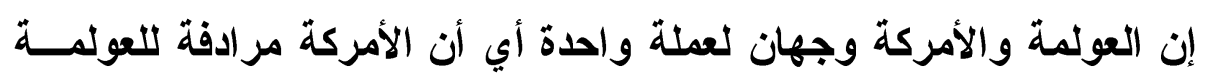

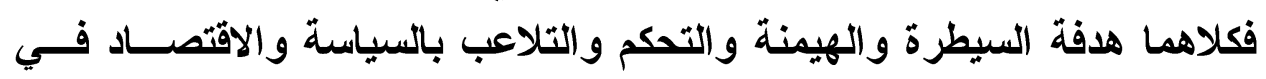

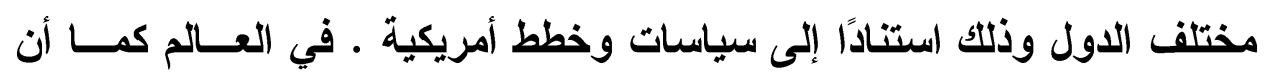

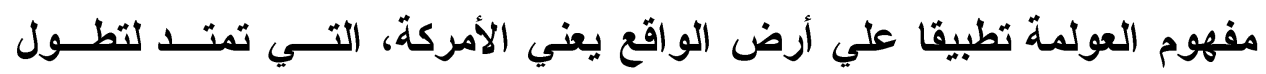

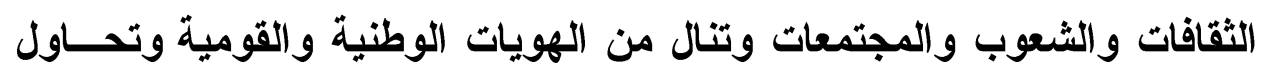

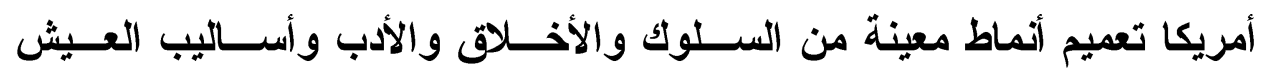

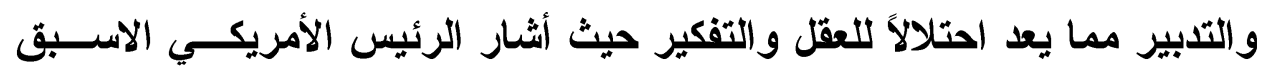

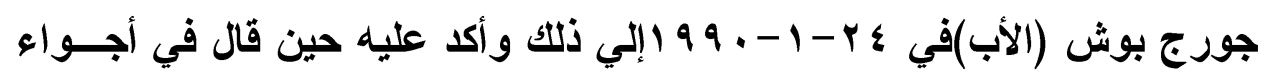

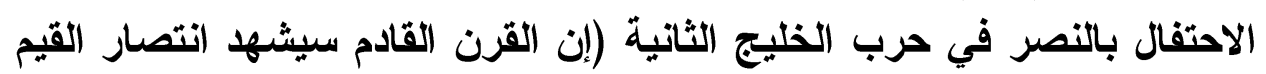

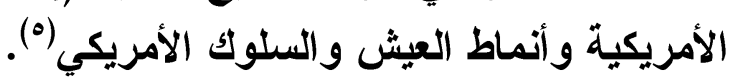




\section{المبهث النالث \\ وظائف الإعلام الثنقافي في عصر العولهة}

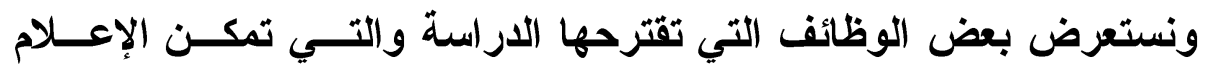

الثقافي من إحداث أثر مهم في عصر العولمة المغالف، منها :

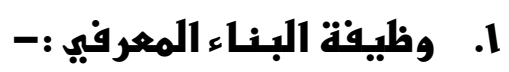

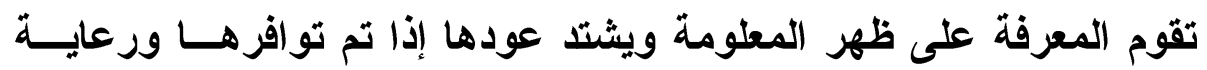

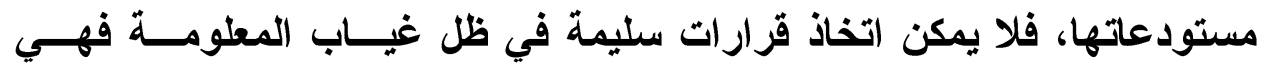

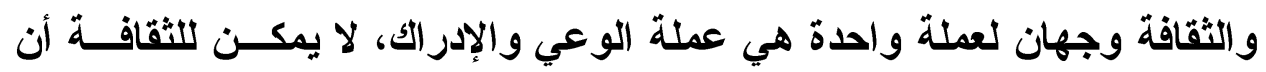

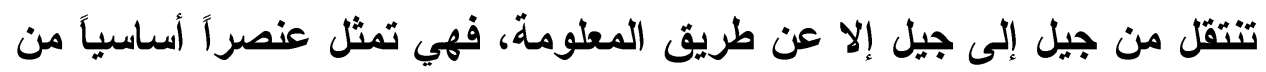

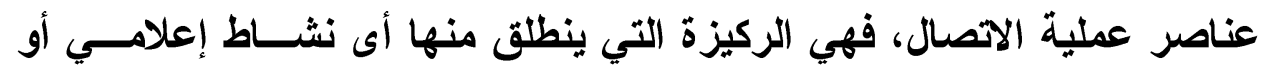

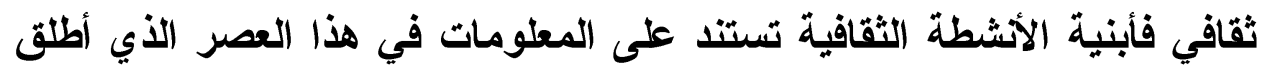

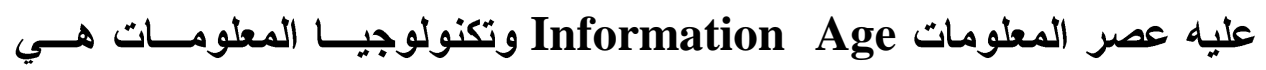
المحرك الرقمي لعملية العولمة إذ أصبحت المسافات تتقلص وتزداد المداد الوشــائج

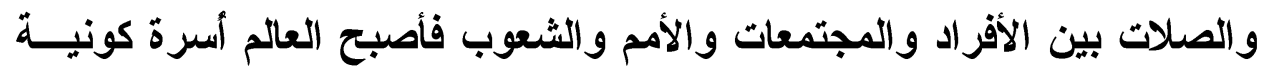

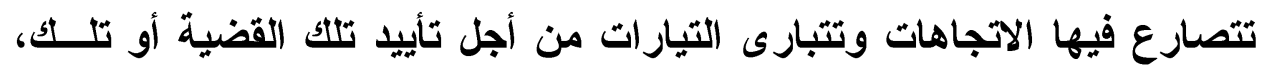

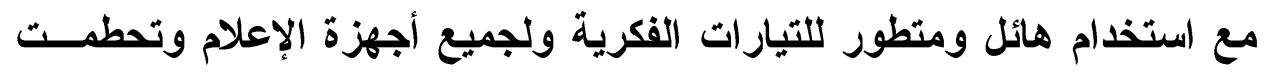

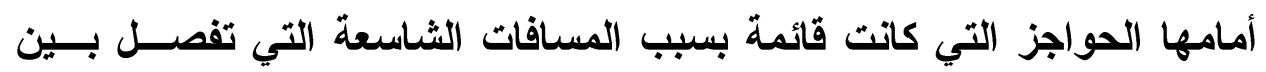

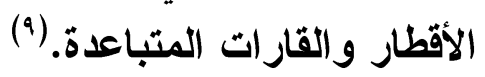

فأصبحت المعلومة لا تحدها حواجز ولا حيز مكاني لذألك يباثـــر الإعــلام

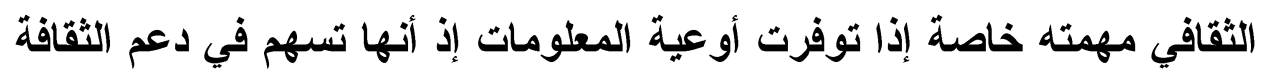

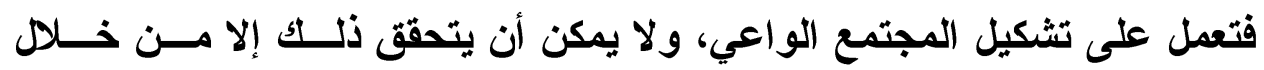

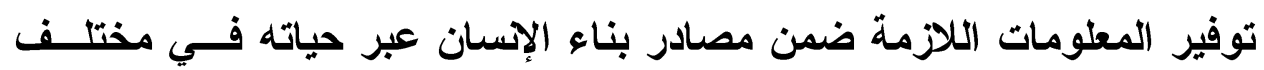

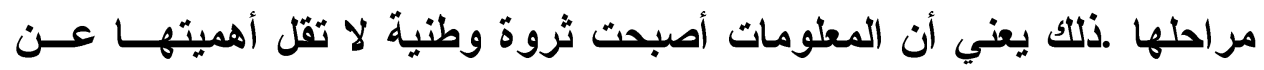

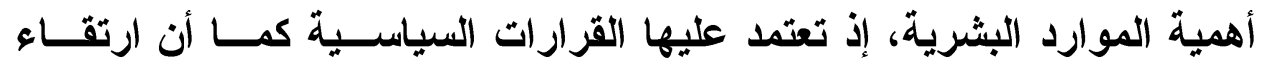

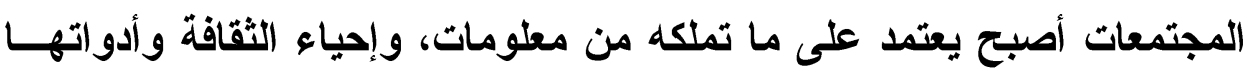

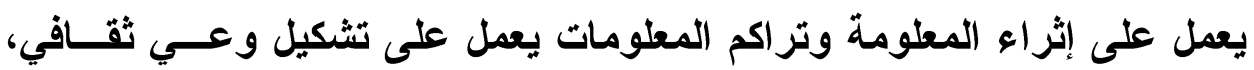
خاصة وأنه في ظل تدافع الصناعات التكنولوجية أصبحت تكنولوجيا المعلومات 
أداة مهمة للرصد والتحليل ومتابعة التفاعلات، كما أصبحت توفر قنوات فعالــة

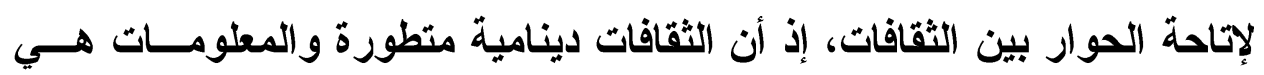
المورد الإسساني الوحيد الأي لا يتناقص بل ينمو مع زيادة استهلاكه (·').

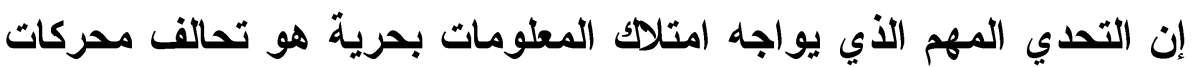

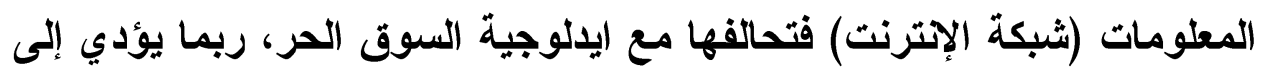

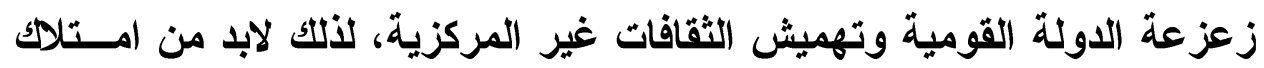

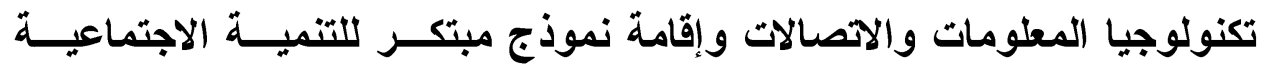

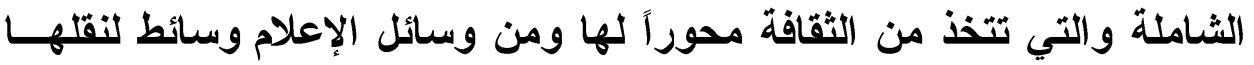
وترويجها ونشرها، فإن من شأن توافر المعلومات، وأهميته في البناء المعرفي

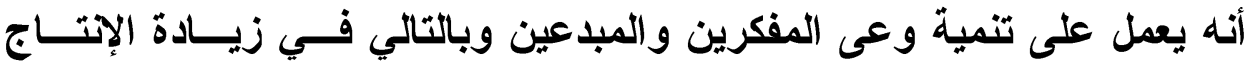

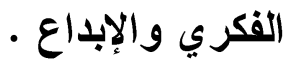
كما أن التوسع في إنشاء المكتبات الرقمية يعمل على إبراز أدوات الثقافـــة

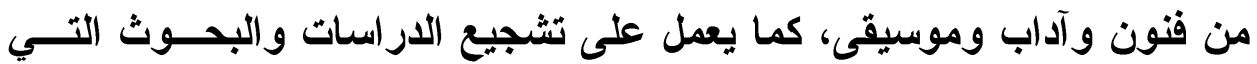

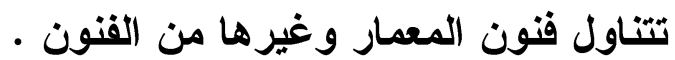

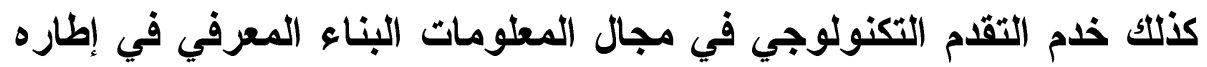

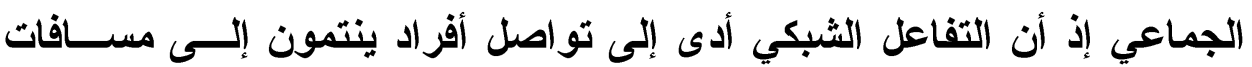

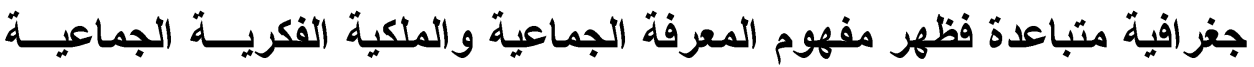

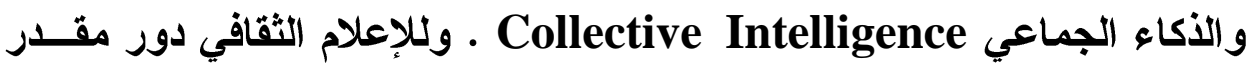

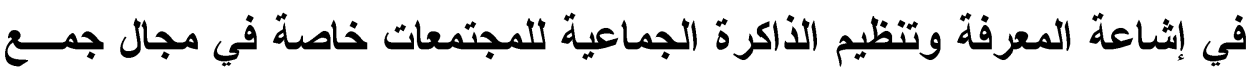

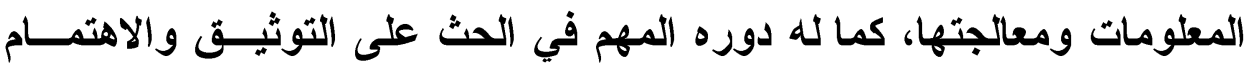

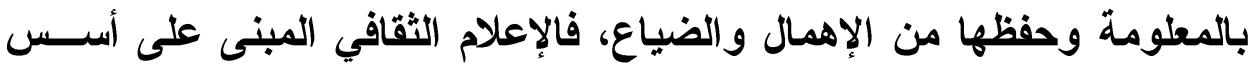

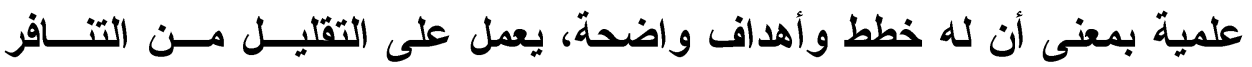
المعرفي وذلك عن طريق التعرض الاتثقائي للمعلومات، فالتوعية الثقافية توفر

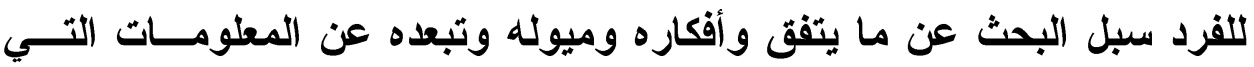

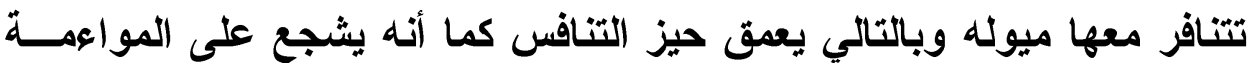

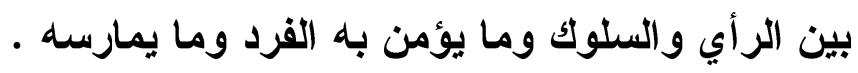

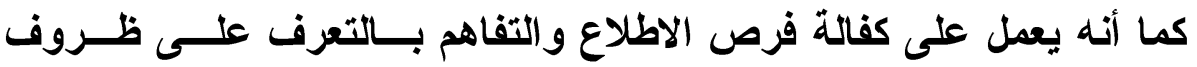
معيشة الآخرين ووجهات نظرهم وتطلعاتهم مما يدعم التكامل والتفاهم، ويمكن 
أعضاء المجتمع من التعايش و العمل المشترك الناتج عـن التواصـل وتبــادل

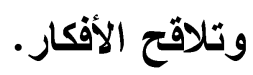

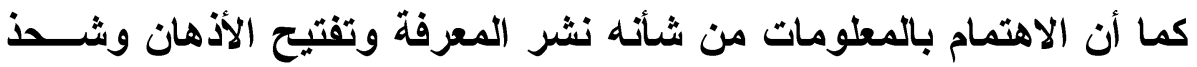

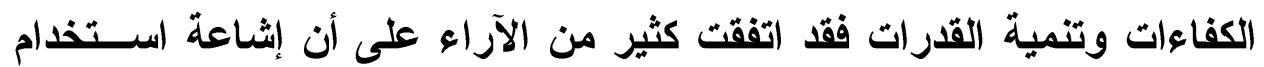

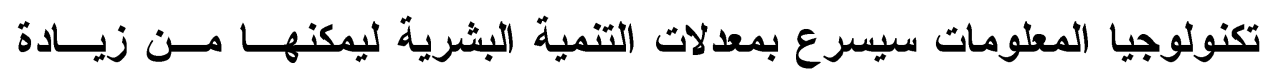

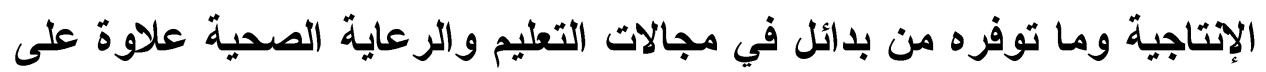

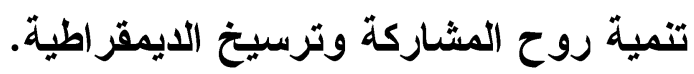

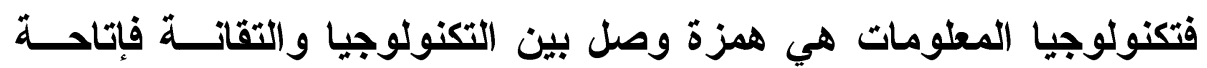

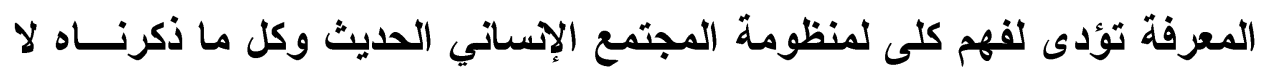

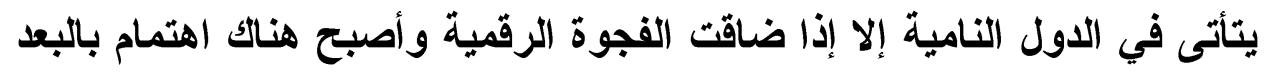

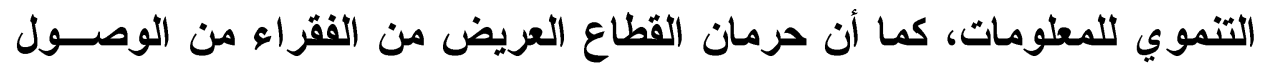

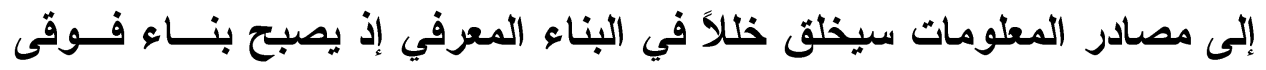

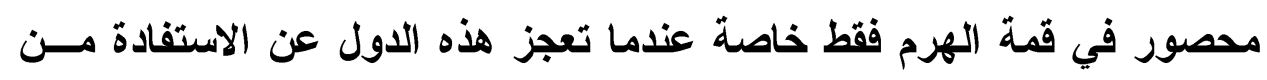

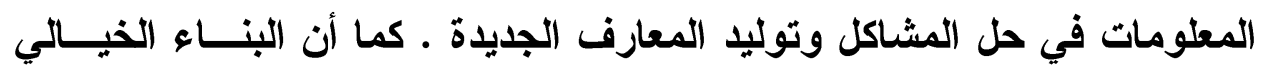
ل المعرفة أيضاً له آثاره الضارة.

\section{tr. م وظيفة هماية الذات الثقافية :}

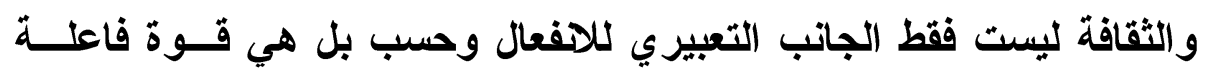

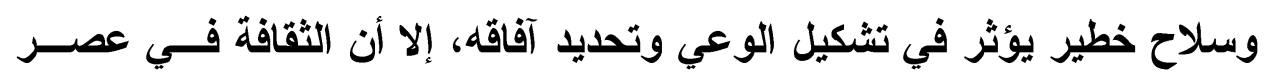

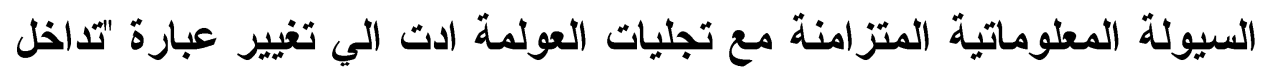

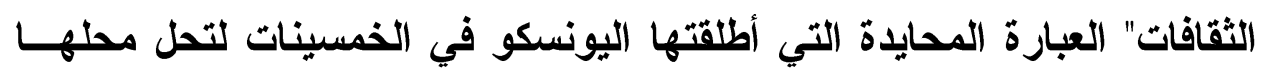

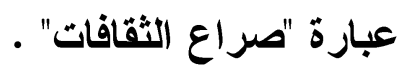

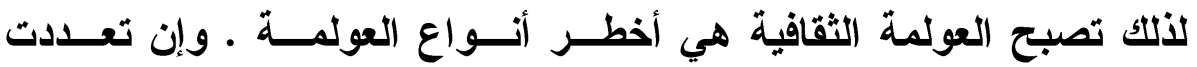

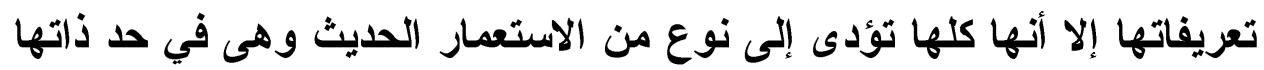

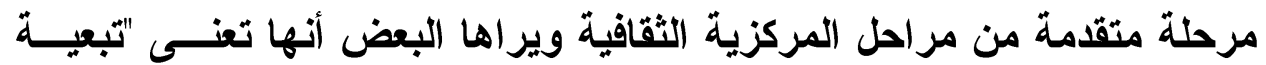

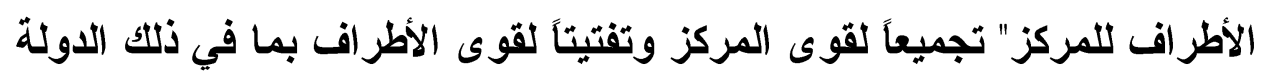

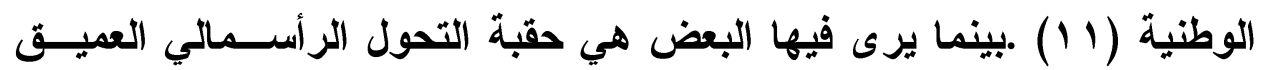

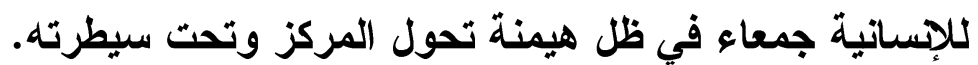


إذن تثقى معظم التعريفات علي أنها تعنى مرحلة التحول الر أسمالى وبــيس

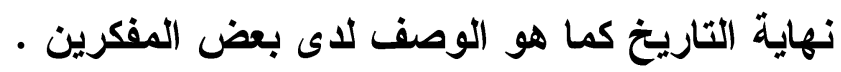
وقد تداخلت الجدليات الفكرية حول ذاتية الثعوب الثقافية الثية وكيفية المحافظة

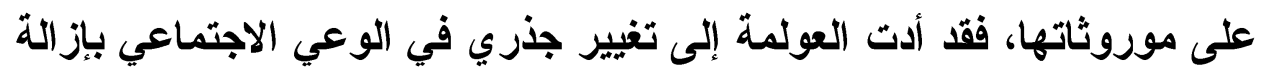

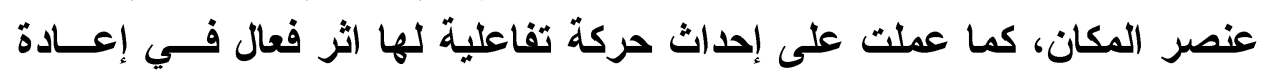

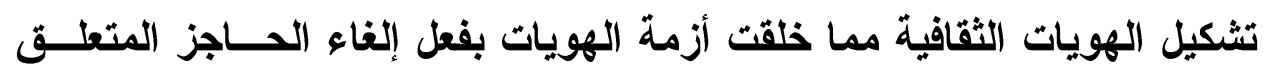

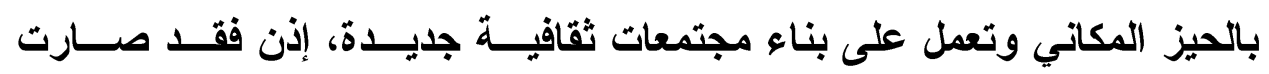

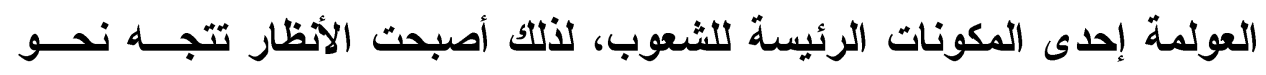

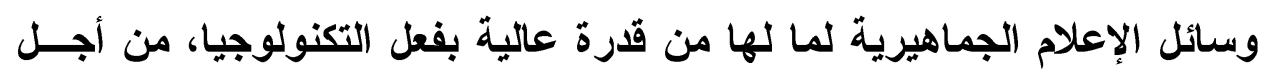

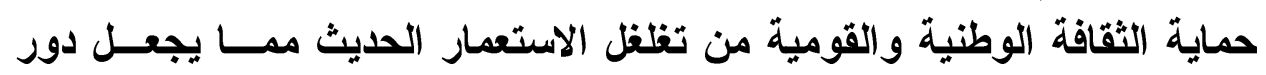

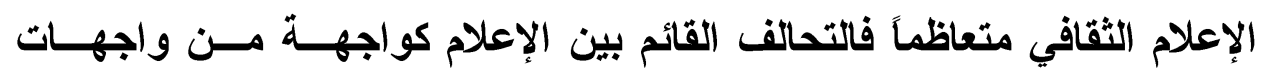

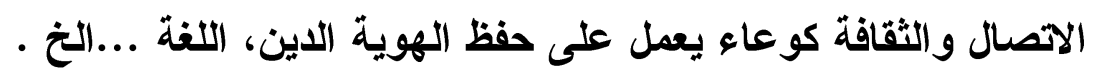

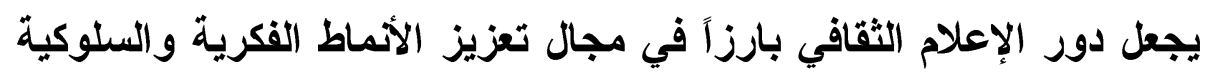

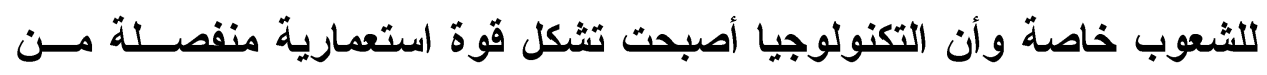

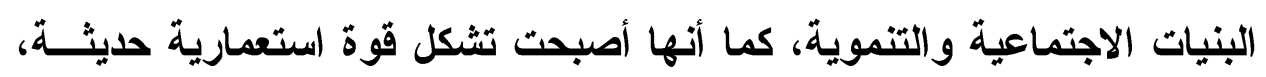

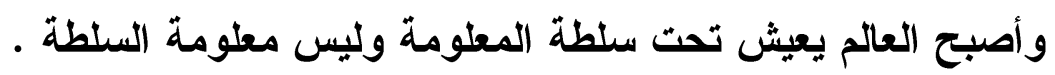

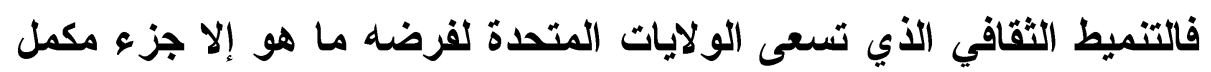

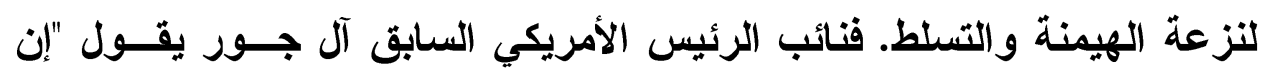

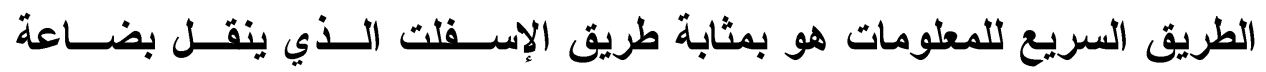

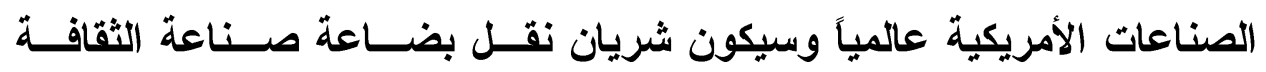

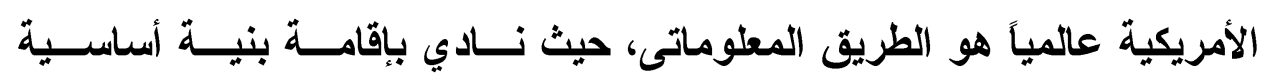

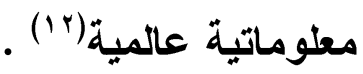

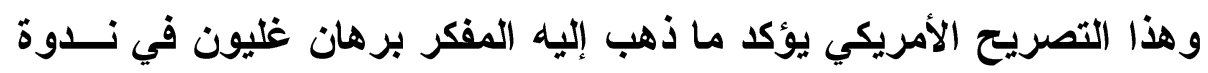

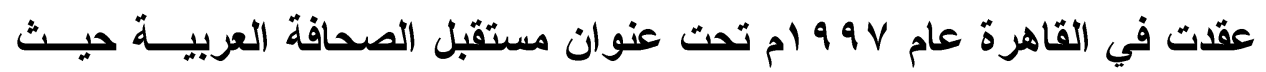

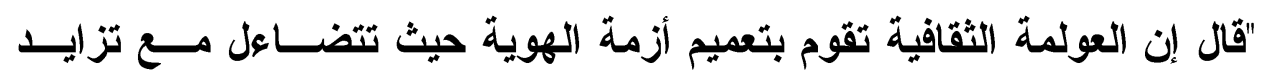

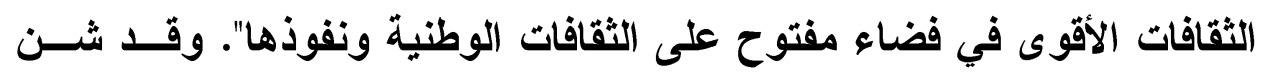

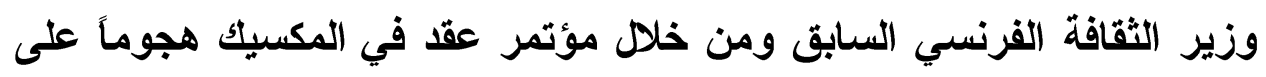




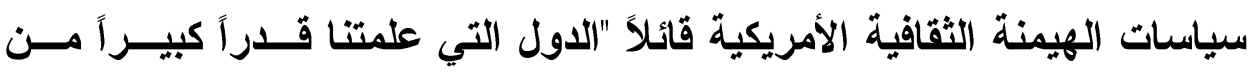

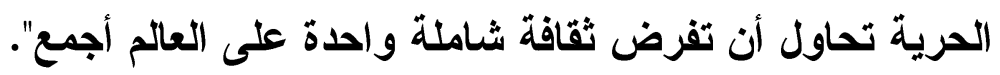

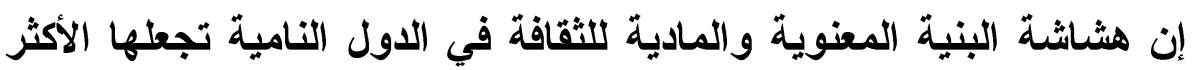

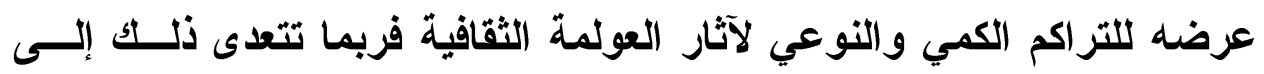

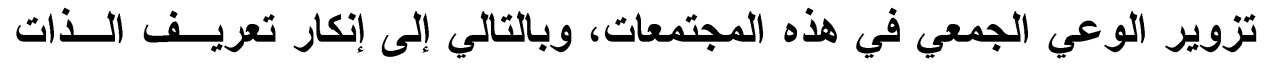

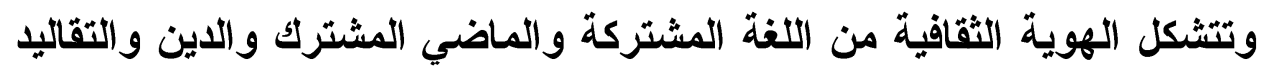

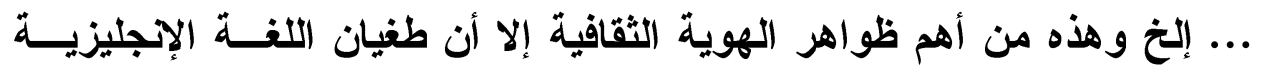

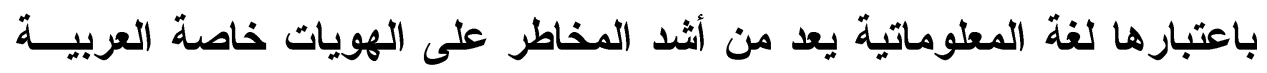

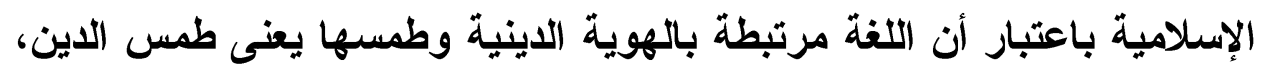

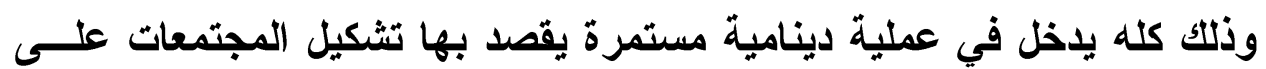

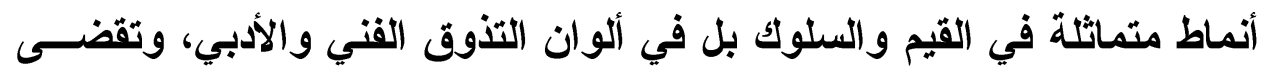

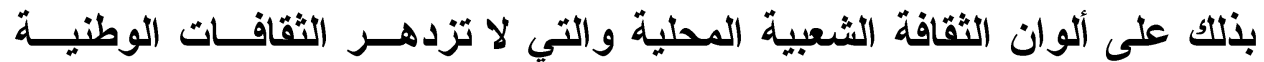
بغير ها.

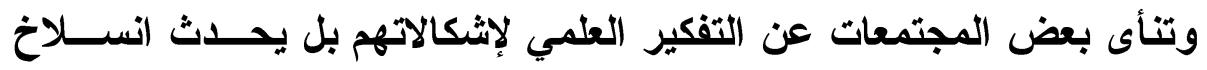

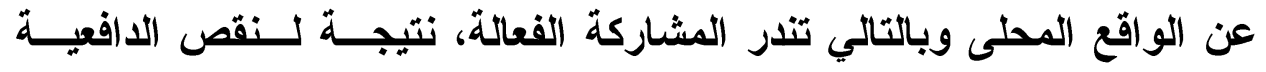

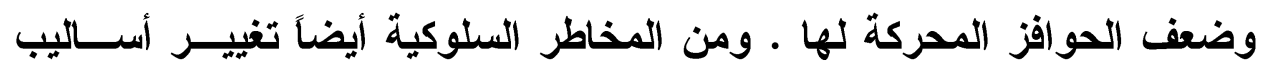

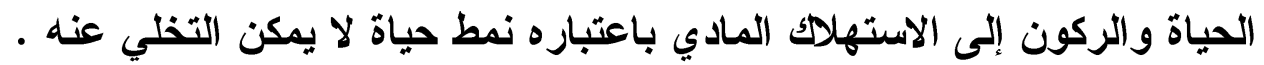

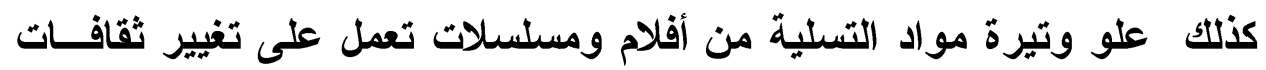

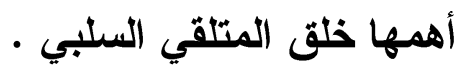

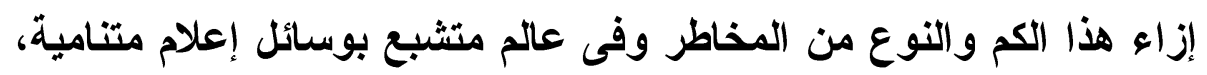

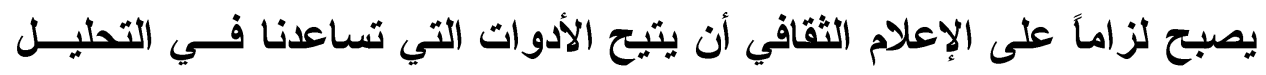

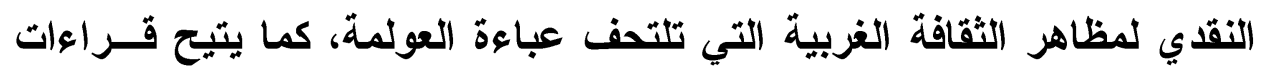

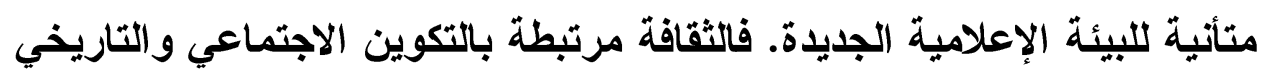

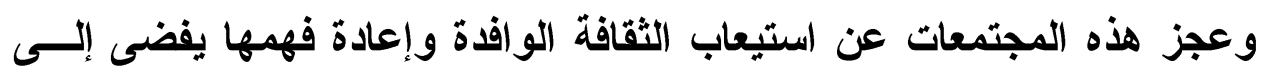

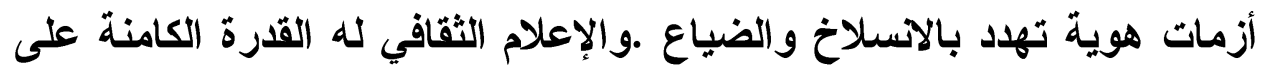

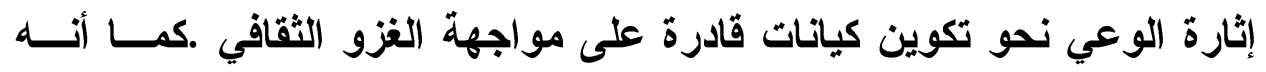

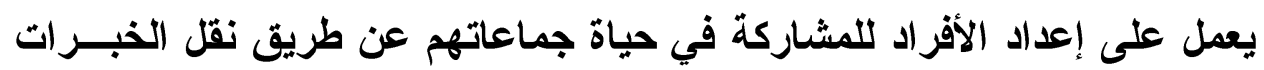

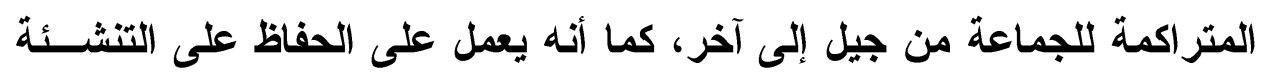


الاجتماعية و العمل على دفع الأنشطة الثقافية وانتفاع الأفــراد بصــفة عامــة

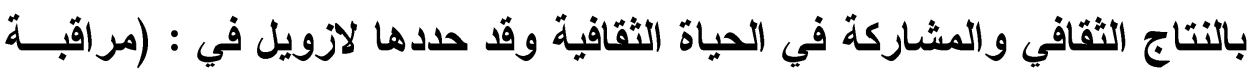

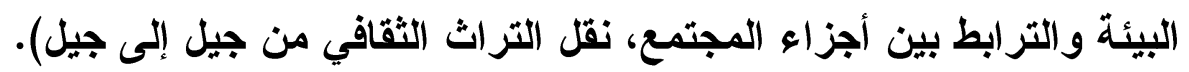

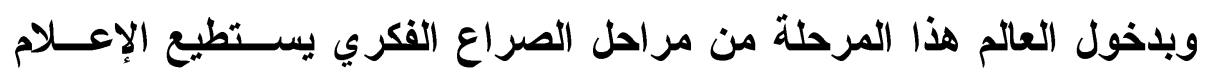

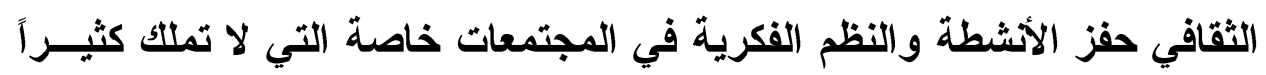

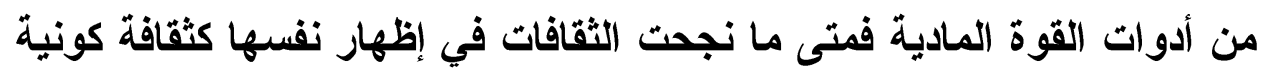

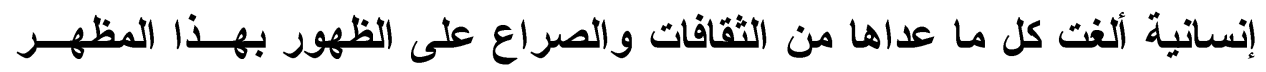

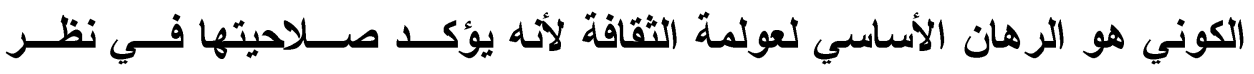
الجماعة التي تحملها والجماعات الأخرى (ri)".

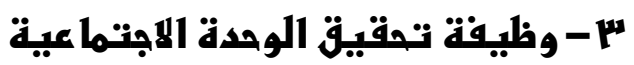

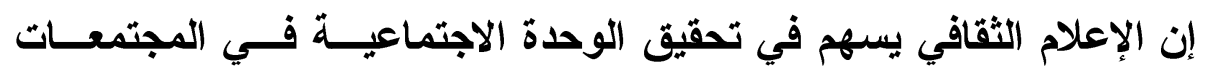

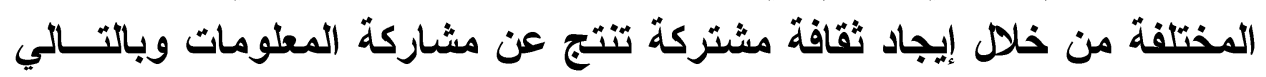

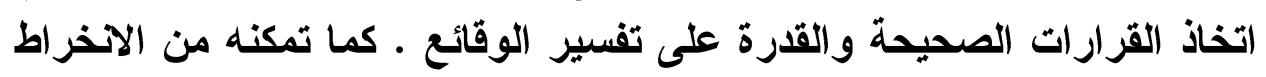

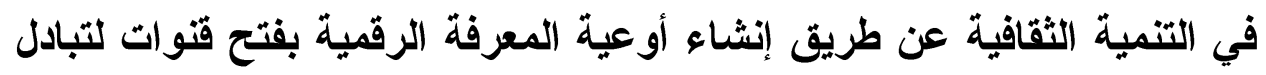
المعارف و الكتب والمستودعات الإخبارية والإعلامية .

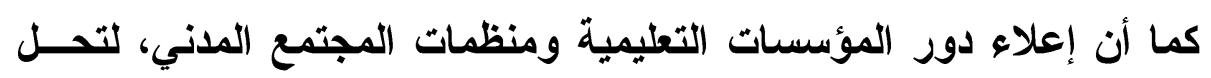

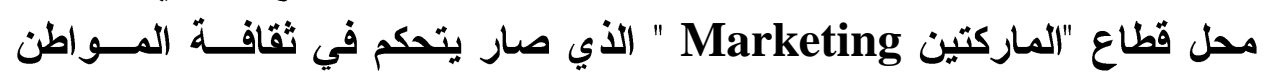

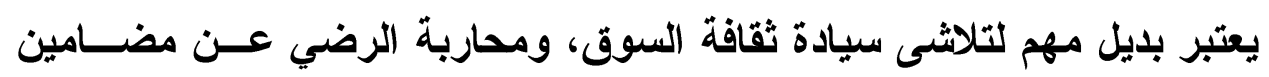

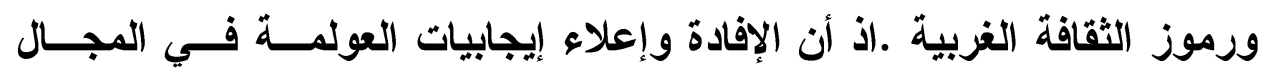

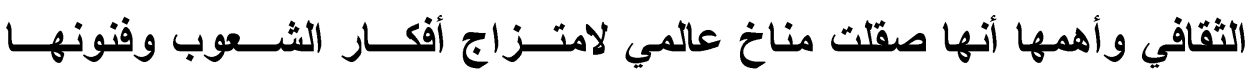

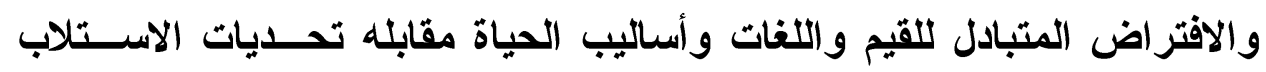

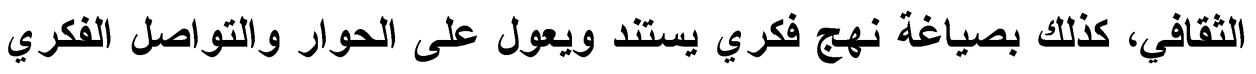

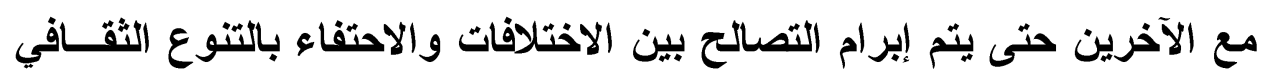

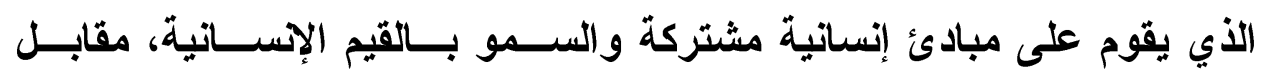

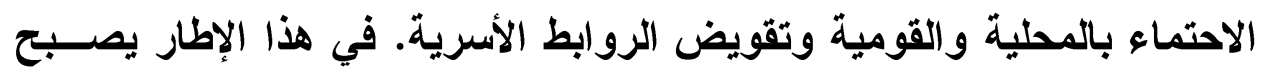

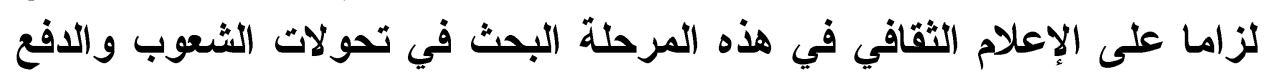


بعثوم تهتم بالثقافات البشرية بعيداً عن التعصب الطــائفي أو الايــدولوجي إذ إذ

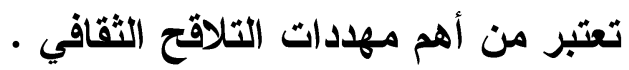

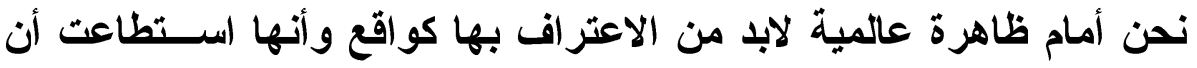

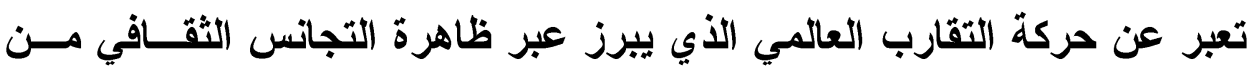

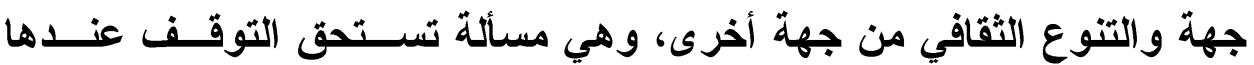

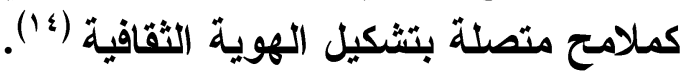

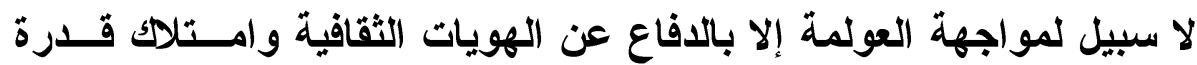

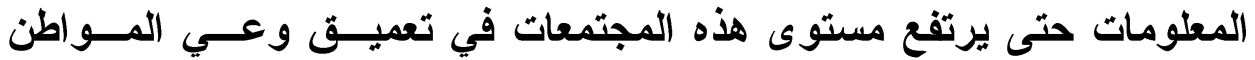

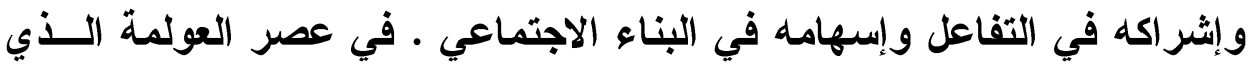

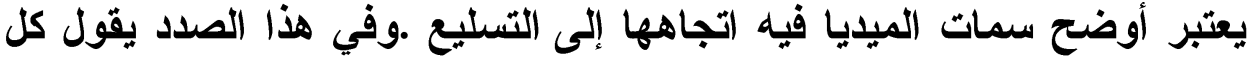

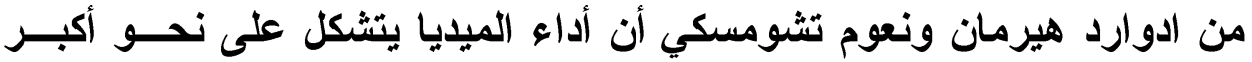

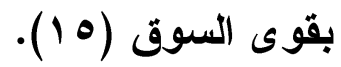

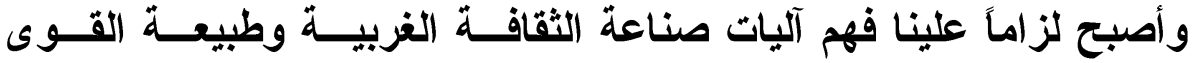

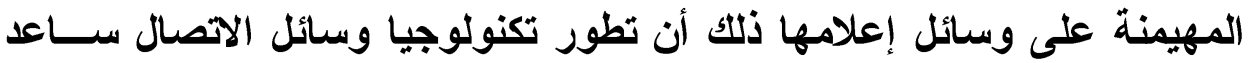

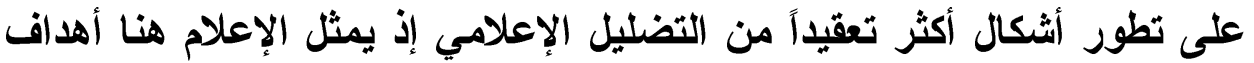

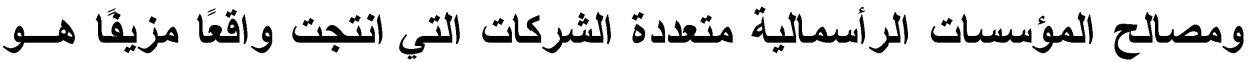
الإكار المستمر لوجود هذا التضليل الإعلامي واستبداله بمفهوم الحياد.

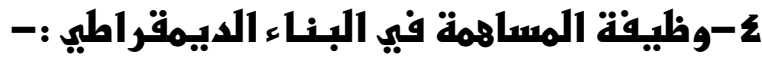

يختص الإعلام الثقافي بدور مهم في تثثييد البناء الايمقراطي وتهيئة التربة

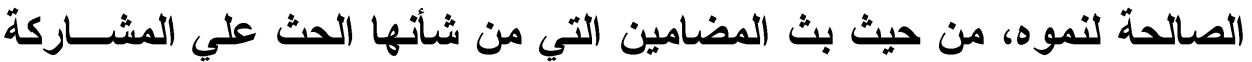

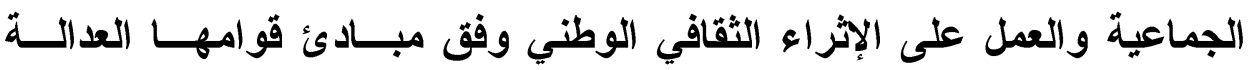
والحرية فلا يقتصر الإنتاج الثقافي على طبقة دون اخرى، كما لابد من تمكسين

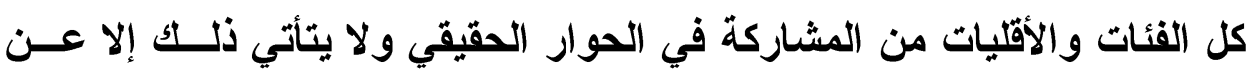

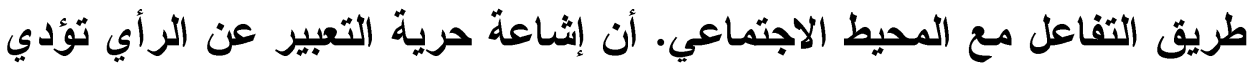

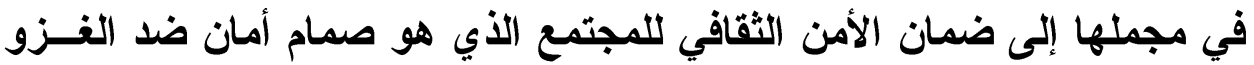

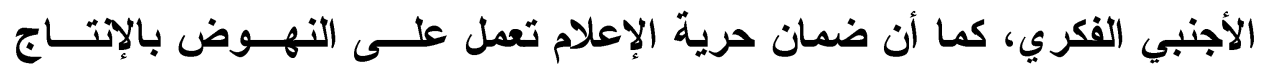

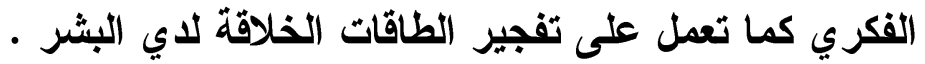




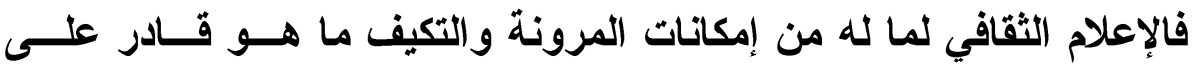

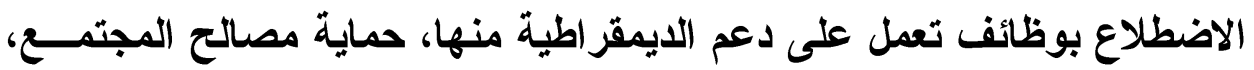

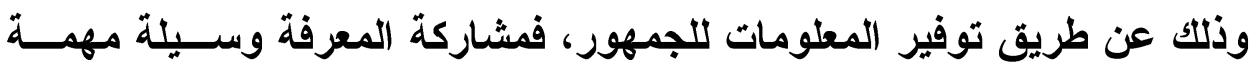

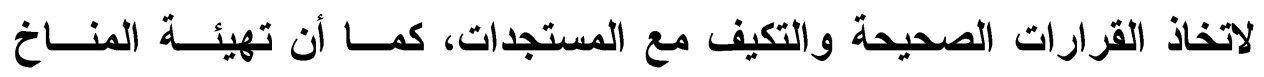

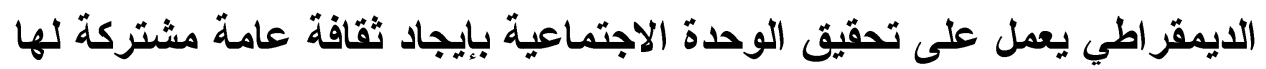

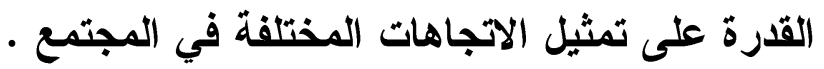

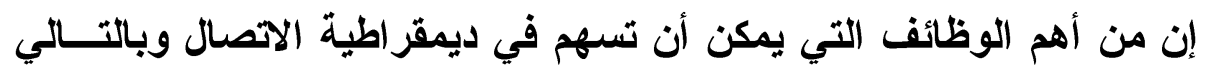

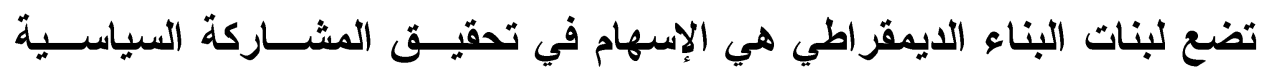

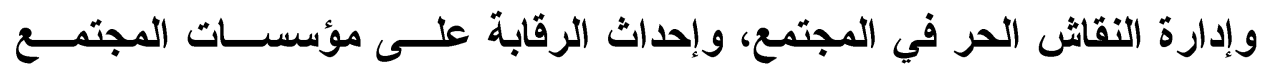

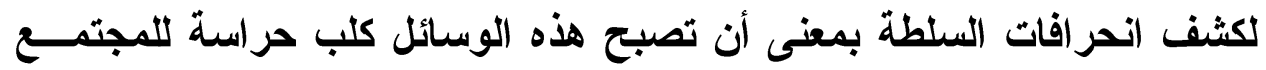
وليس للسلطة .

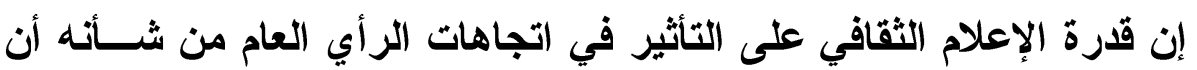

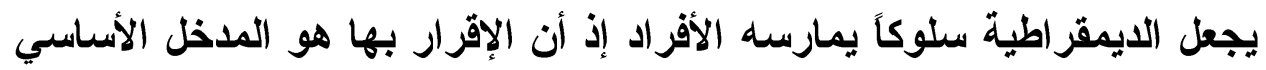

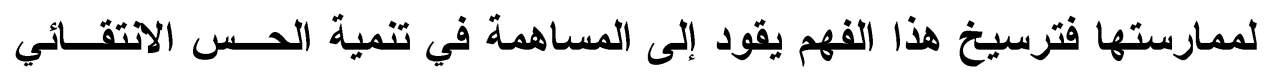

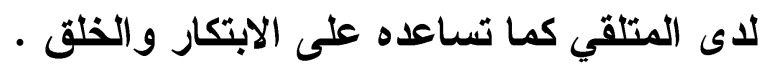

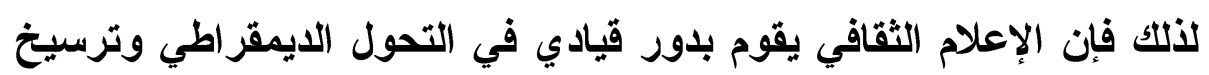

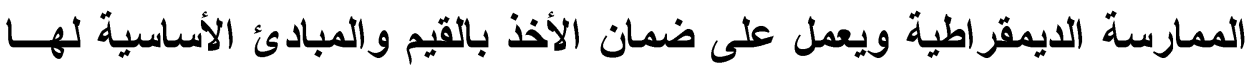

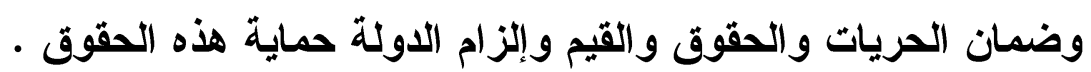

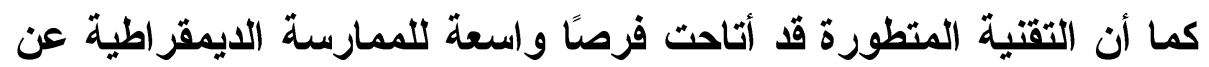

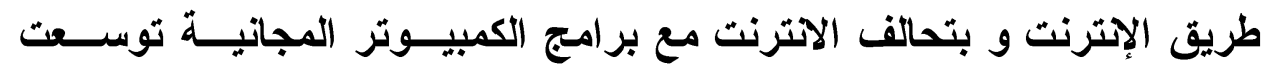

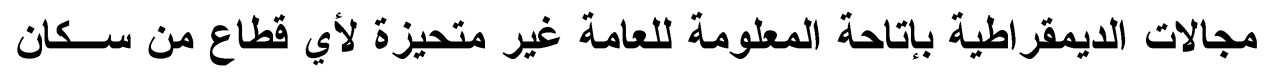

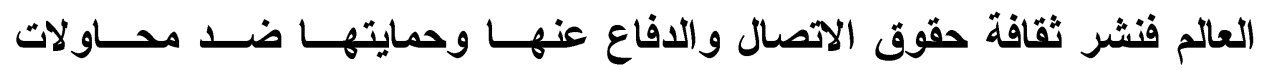

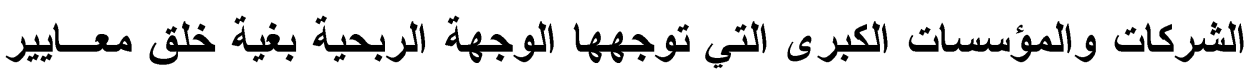

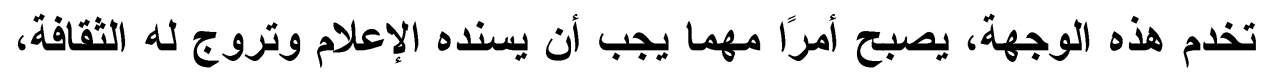

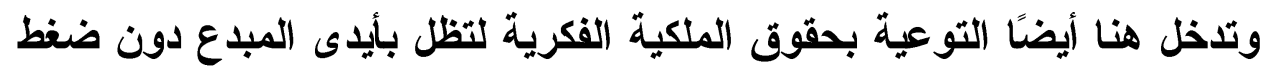




\section{0-وظليفة العوار}

يستتد الإعلام الثقافي علي أهم وظائفه وهي وظيفة الحسـوار اذ أن مســـألة

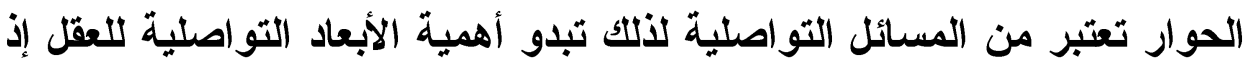

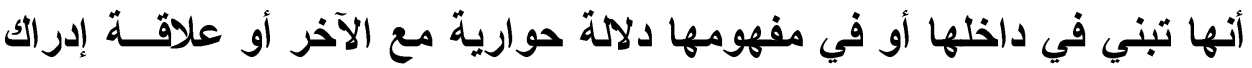

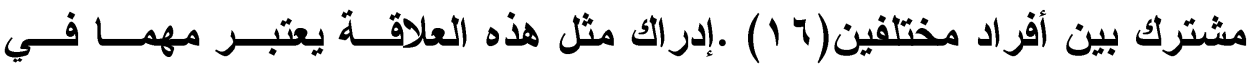
الوصول لفه حجج أو براهين الآخر ذلتك يعني أن التواصل العقلي وتداعياتــه

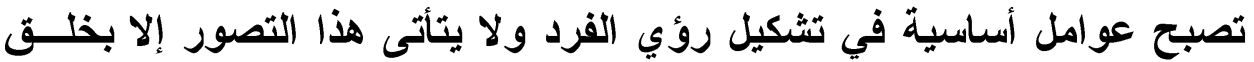

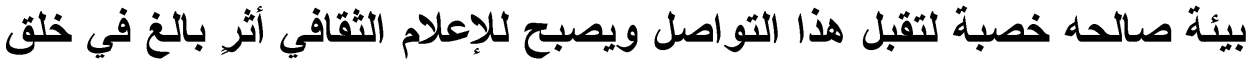

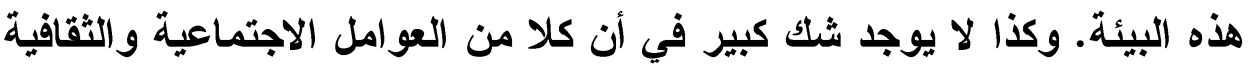

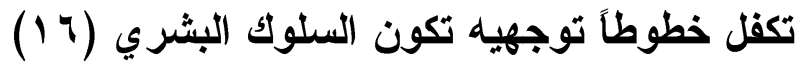

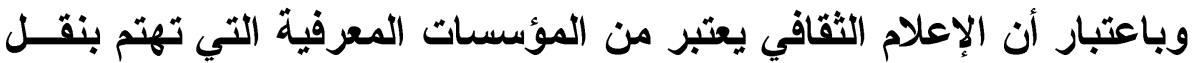

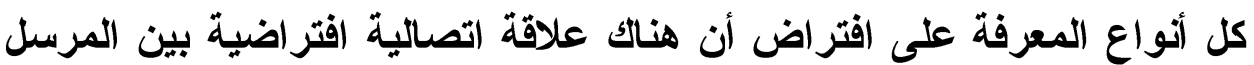

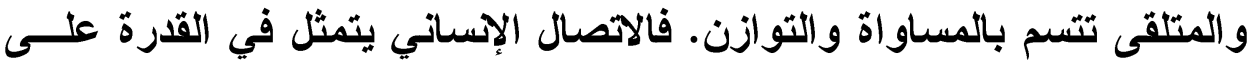

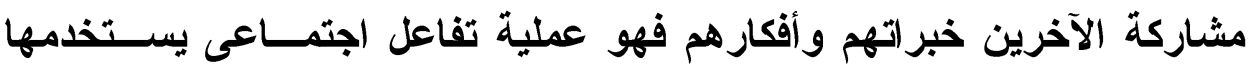

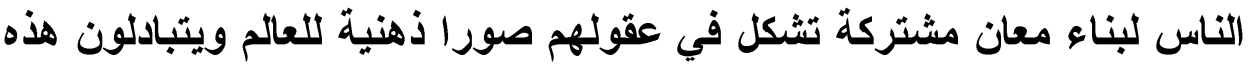

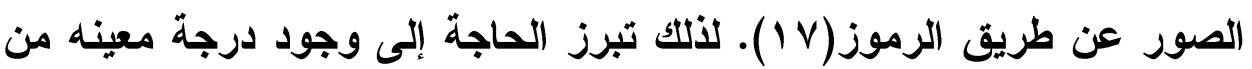

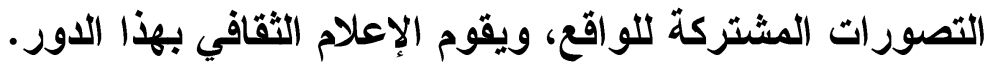

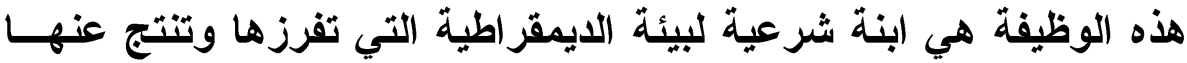

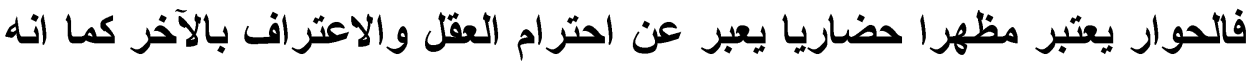

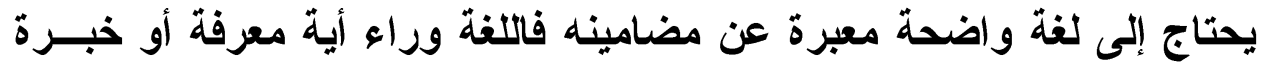

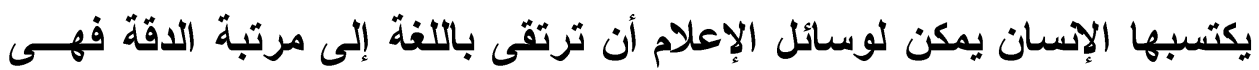

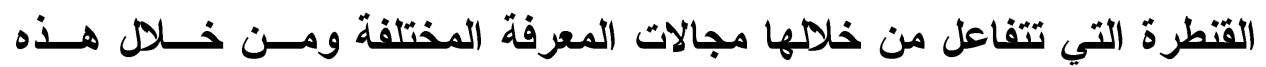
الوظيفة تتجلى أهمية وسائل الإعلام.

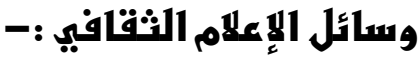

نثه في هذا العصر تضاؤل دور الوسائل التقليدية امام هذا الكم الهائل من

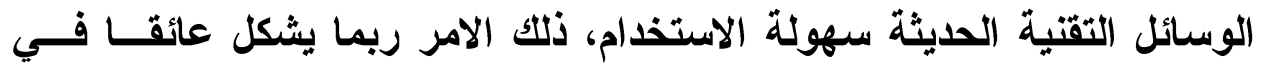

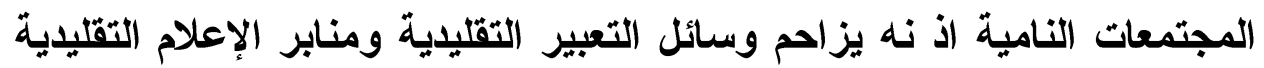
في الارياف، وكل ما من شأنه دعم المجتمع المحلى فيعمل علي ترهل النسـيـيج 
الاجتماعي للمجموعات البشرية التي تحاول أن تدعم التضامن والانسجام داخل مكوناتها المحلية ويضعف نتيجة لذلك الاتماء والوعات الوعي المشترك بمشكلات هذاته

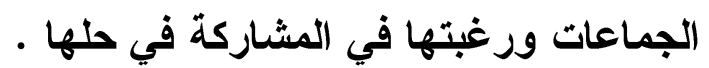

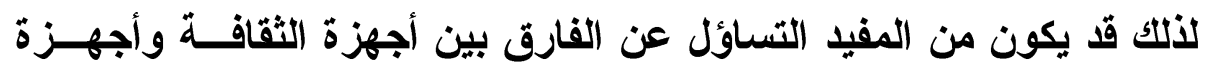

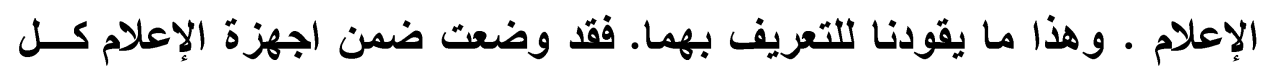

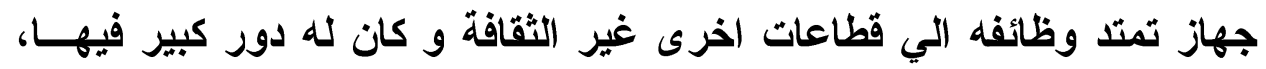

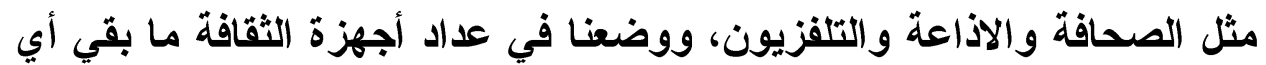

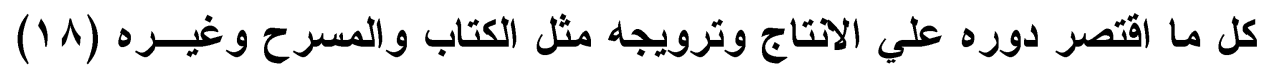

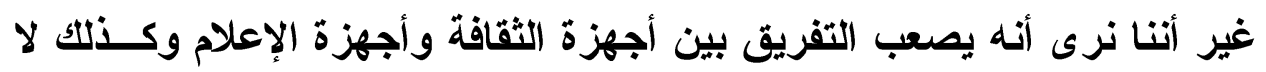

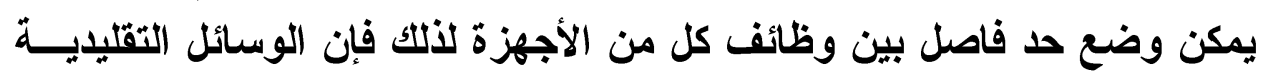

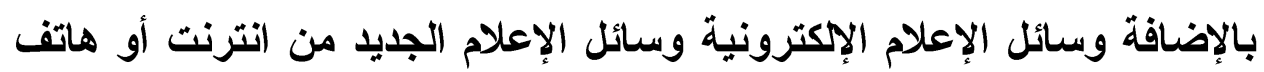

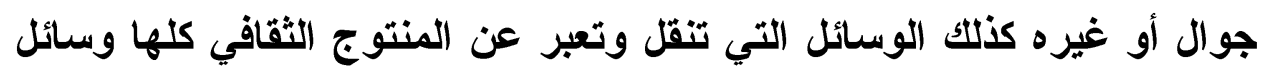

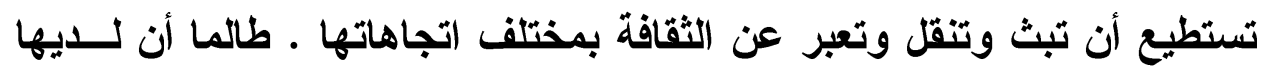

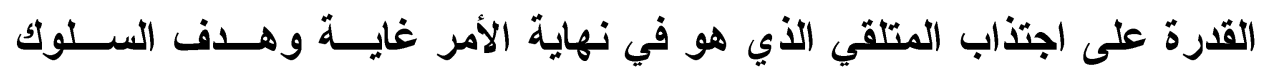
الاتصالي عن طريق إعداد الرسالة الثقافية وإبلاغها.

\section{1-وظليفة طرح بدائل ثقافة التسلية}

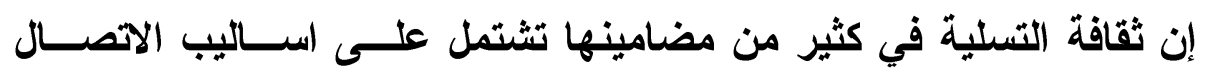

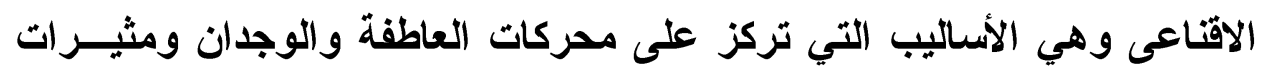

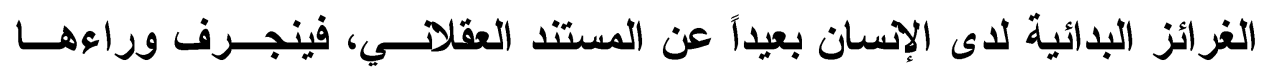

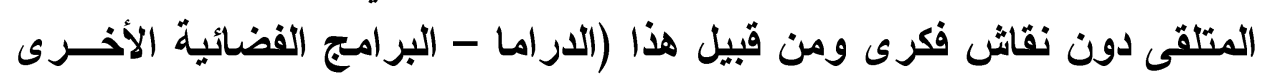

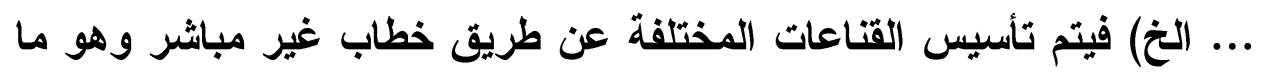

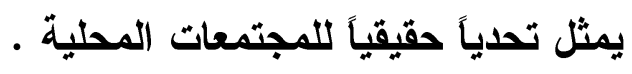

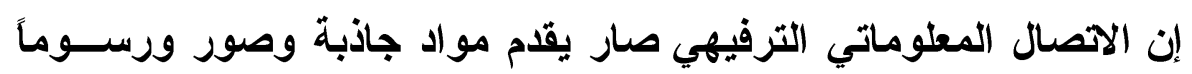

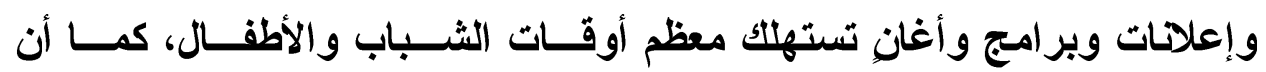

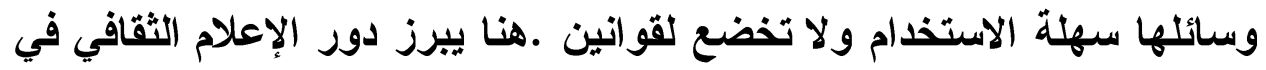

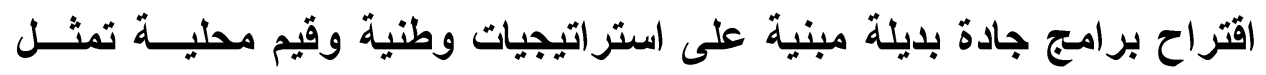
منافسا حقيقيًا لتحديات ثقادة بلة مينة التسلية الغربية . 


\section{V-وظليفة اهداث النقارب بين الثقافات}

تعد ظاهرة الاتصال بين الأفر اد والامم والثشعوب، ظاهرة قايمة قام الإنة الإسان

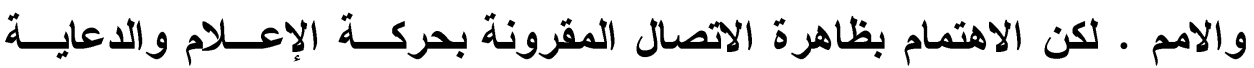

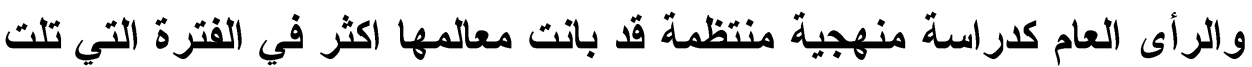

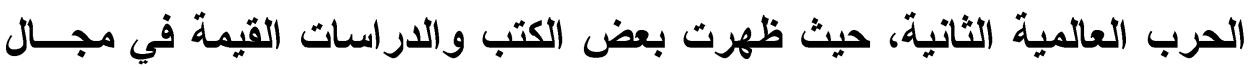

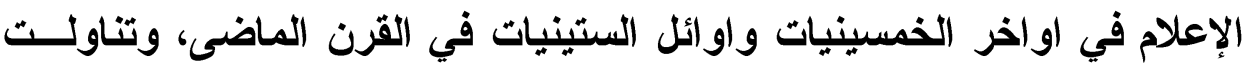

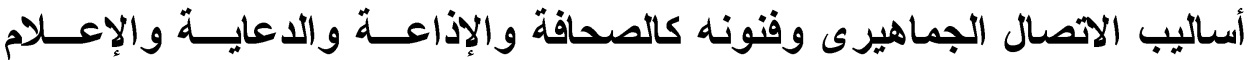

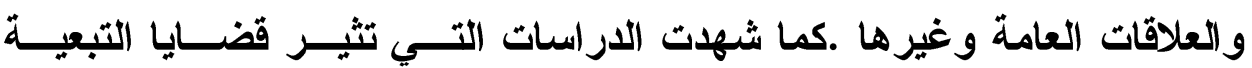

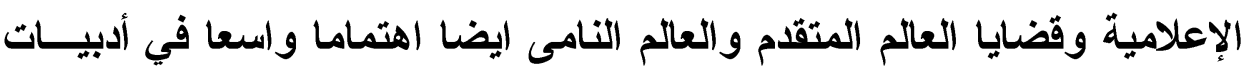

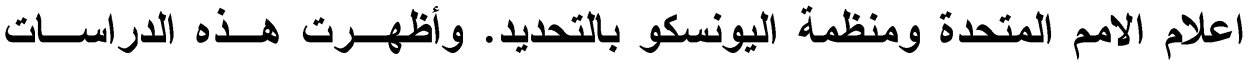

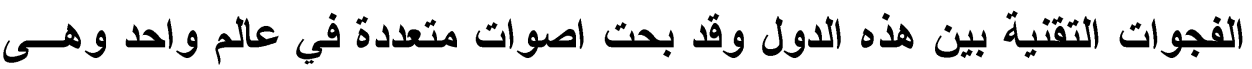

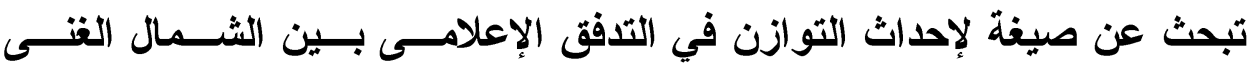

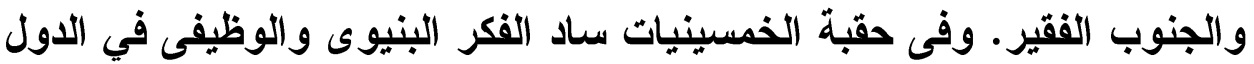

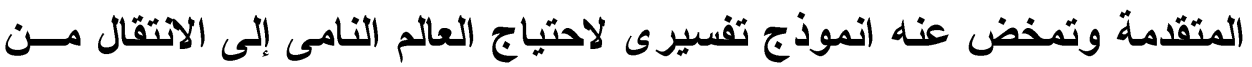

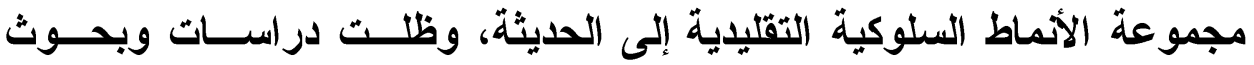

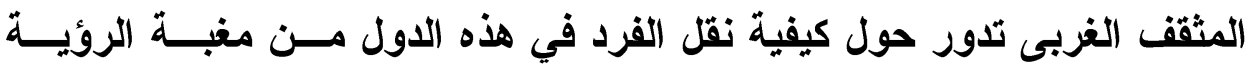

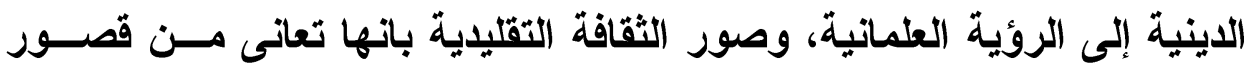

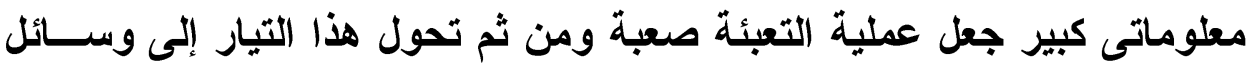

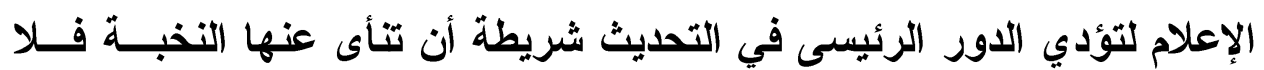

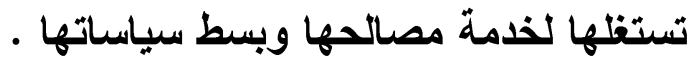

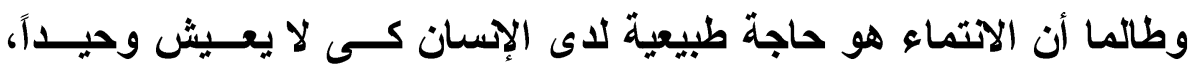

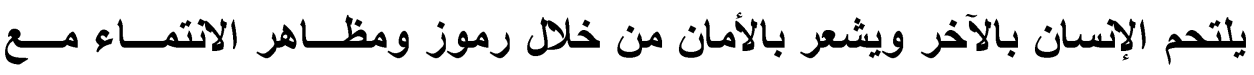

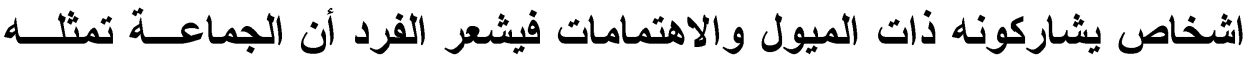

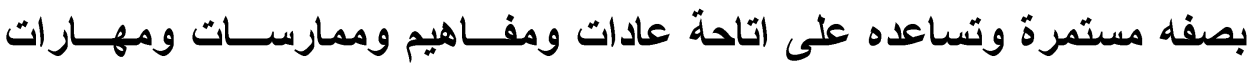

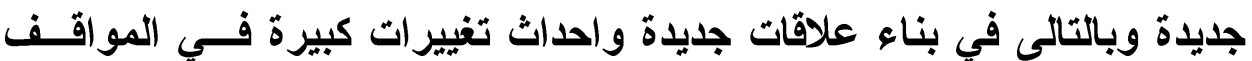

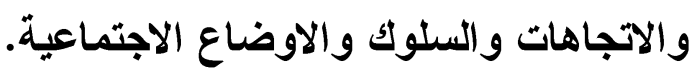

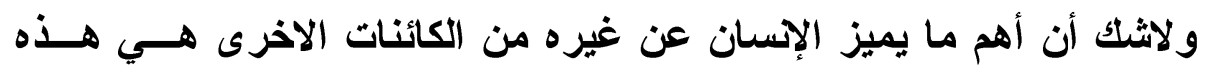

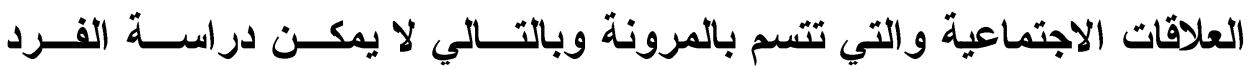


والجماعة البشرية بمعزل عن الظروف المحيطة بهما، وكما قلنا فانه لابد مسن

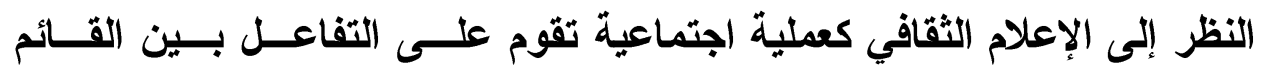

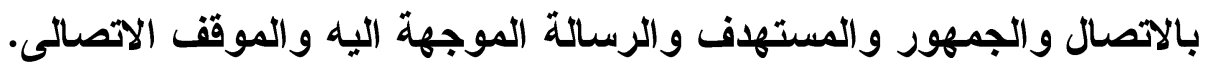

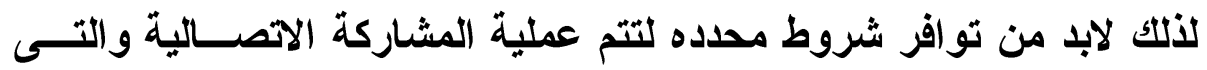

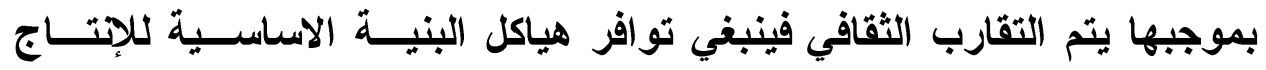

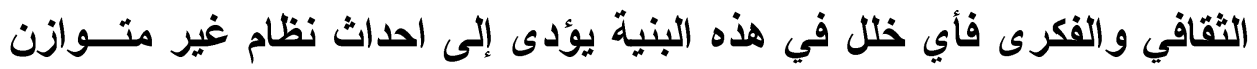

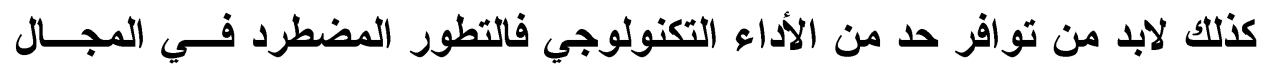

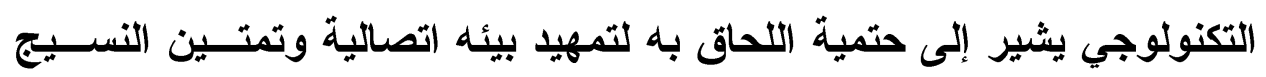

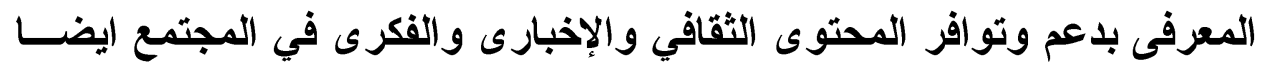

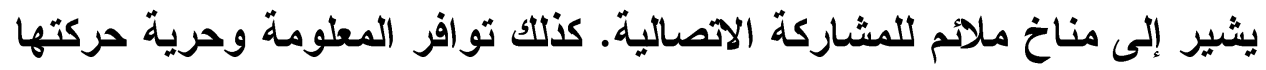

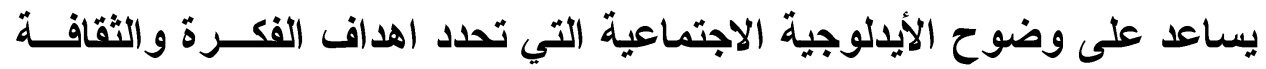

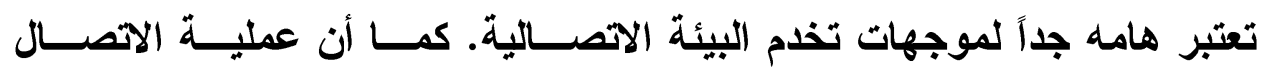

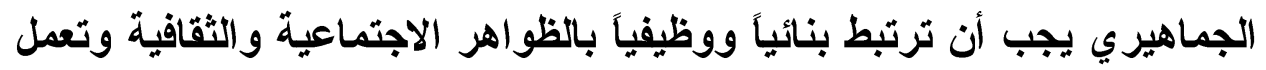
على تحقيق التكامل الاجتماعي والسياسي. كذلك ربط الفرد بقضئسايا مجتمعسـه

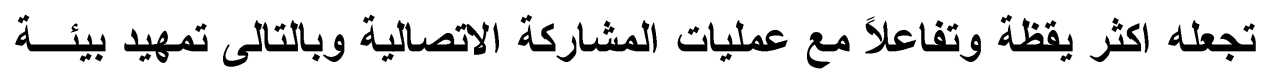

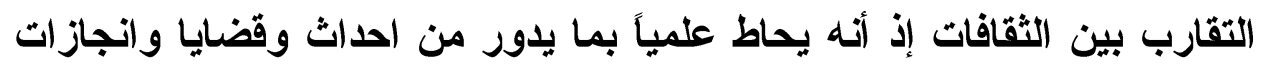
سياسية واجتماعية وثقافية تكون حافزاً ودافعاً لمشاركة اتصالية فالئ فاعلة.

\section{^-وظيفة تنشكيل الهوبة}

يقوم الإعلام الثقافي بلور مقدر في تشكيل الهوية مستتلًا على أهم وظائفه

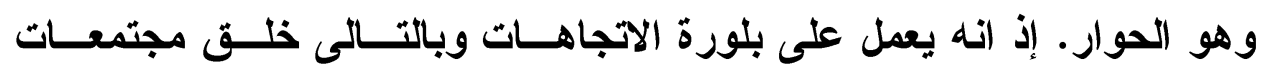

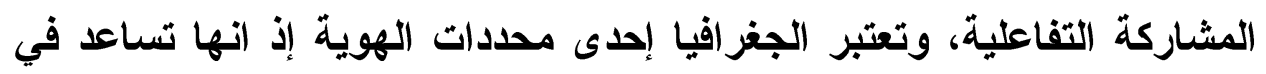

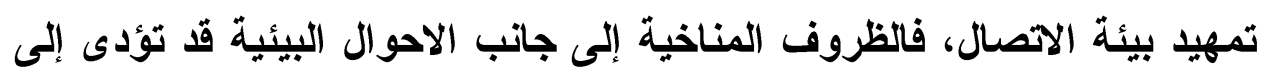

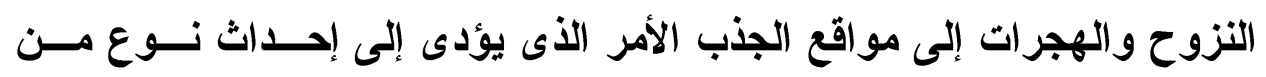

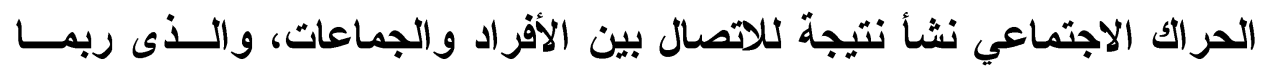

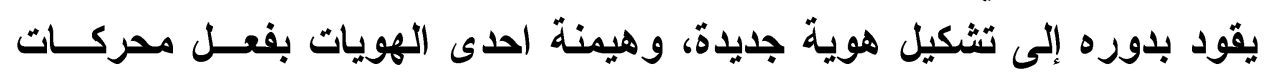

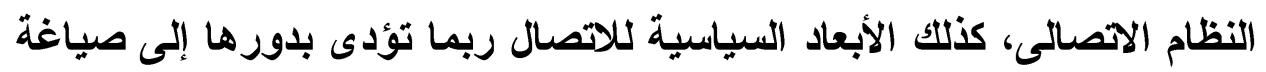

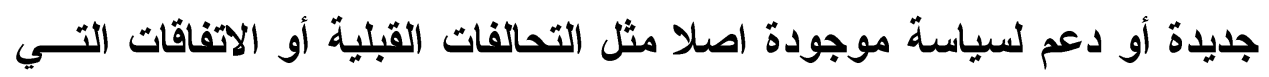


تنص بنودها على محفزات الاتصال ـ ففى واقع التنوع العرقى والثقافي ربمــا

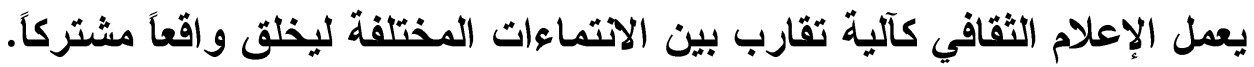

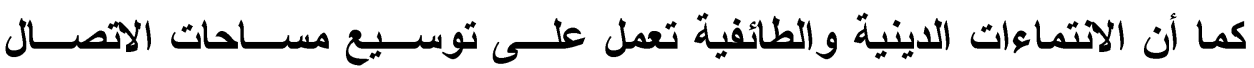

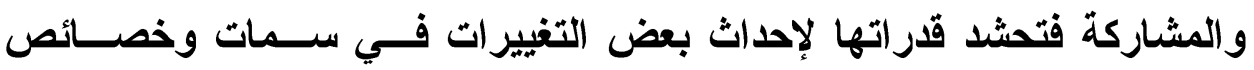

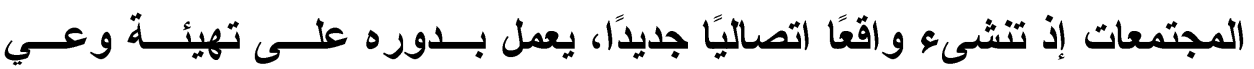

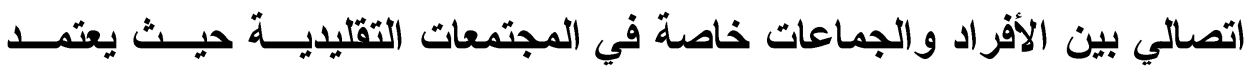
الاتصال على المواجهة المستمدة من السياسات والاعراف التي تم تبنيها محليا

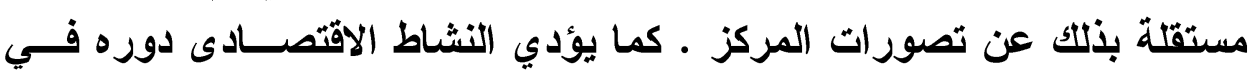

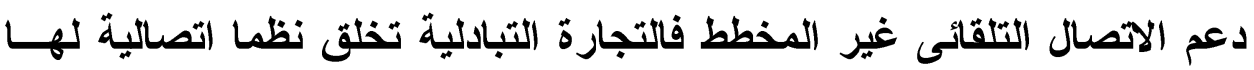

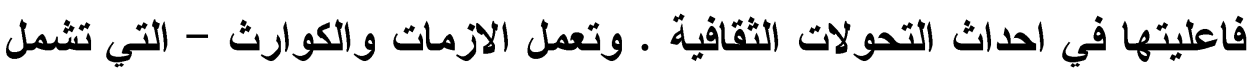

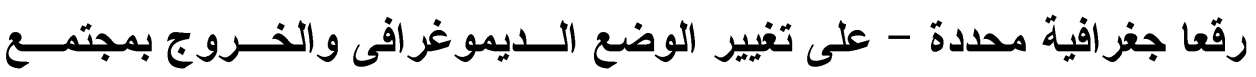
مختلف له سمات اكثر تحديدًا. الا أن بعض المعيقات ربما تثكل عائقًا أمام الإعلام الثقافي ليضطلع بلدوره كمحفز للتقارب الثقافي من خلال تهيئة بيئة المشاركة الاتصالية نذكر منها:

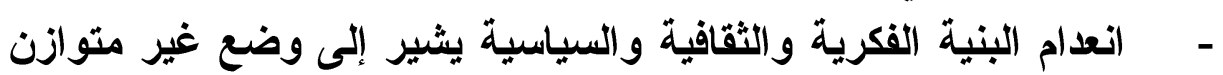
يؤثر سلباً على عملية المشاركة الاتصالية.

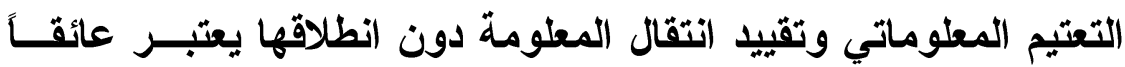

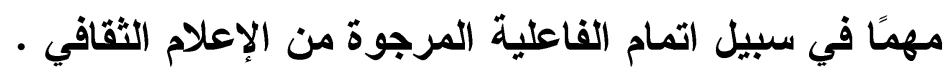

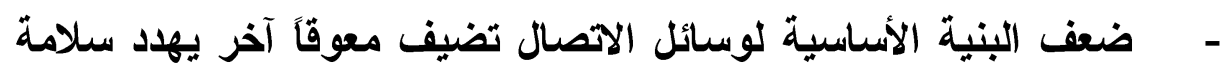

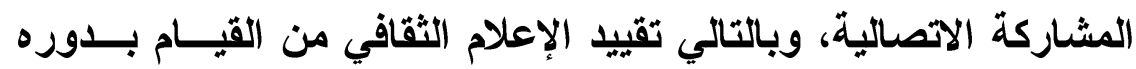

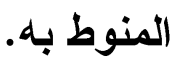
- - التركيز على مجموعة اتصالية دون غيرها يصرف بقية المجموعـات

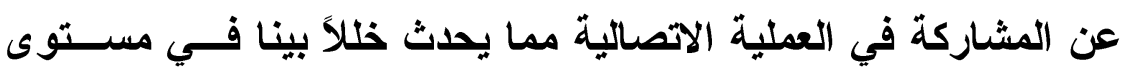

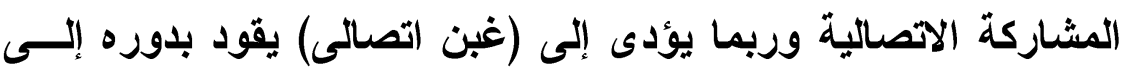
ظواهر اجتماعية سلبية.

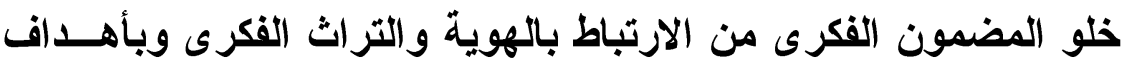

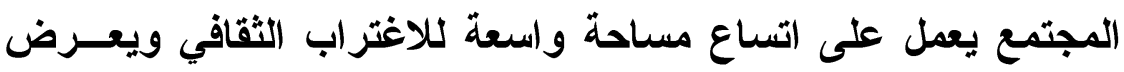

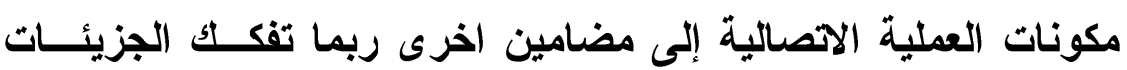


المكونة للنسيج الاجتماعي ويفقد المجتمع طابعه الخاص بــهـ نتيجـــة

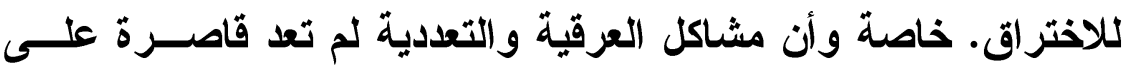
الاول النامية إذ يثهر هذا القرن اهتمامـا متزايـــا بنفــوذ الســلالات

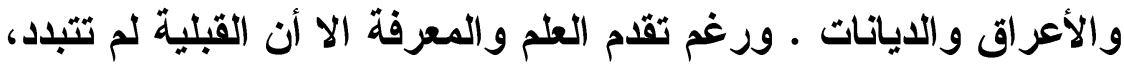

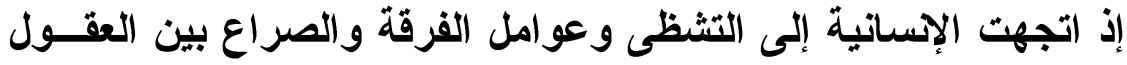

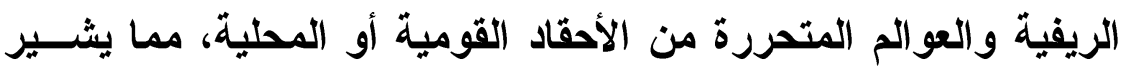

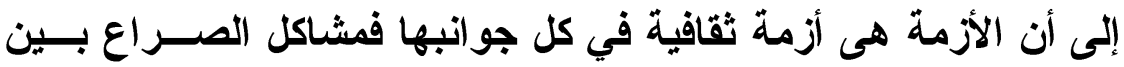

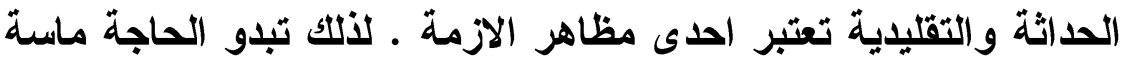

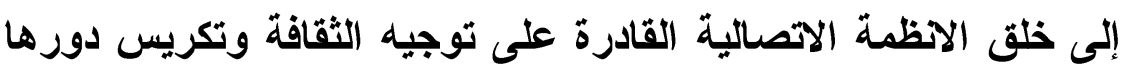
في تعديا معالم المجتمعات إلى جاتب تقوية وربط الآسجة الإنه الاجتماعية

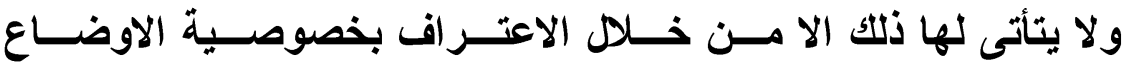

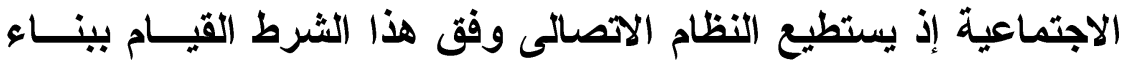

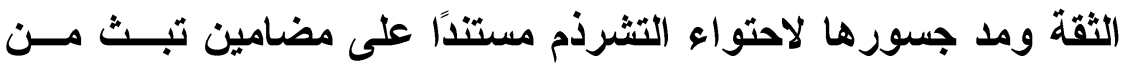

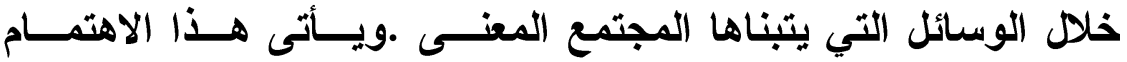
بالثقافات المحلية وهو اهتمام بالأجزاء التي يتركب منها الكل الثة فــافي القومى وهى الثرايين التي تبث في الجسد القومى الحياة ـ كما ساعد التهاء في انتشار اللغات المختلفة وتعد اللغة عامل توحيد بالغ التئ الأهمية ويمكن القول إنها من الثروط الاستاسية لقيام أي مجتمع.

\section{النتنائم والتوصيات}

من العرض السابق يتضح لنا أنه لابد من توافر هياكل البنيــه الاسـاسـية والإتتاج الثقافي والفكري فأي خلل في هذه البنية يحدث نظما غير متوازنة فئة

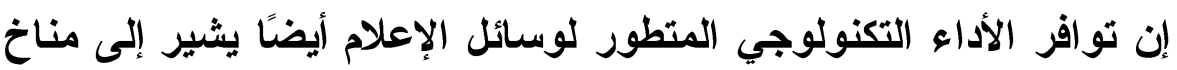

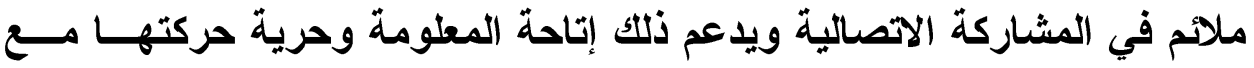

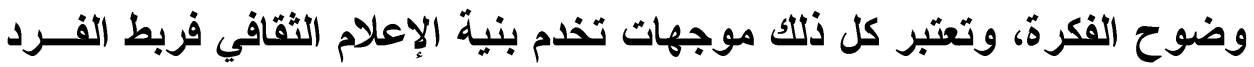

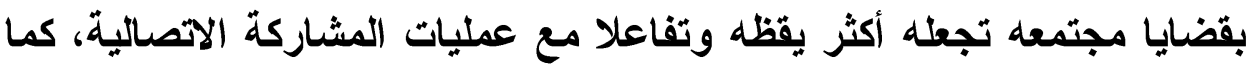

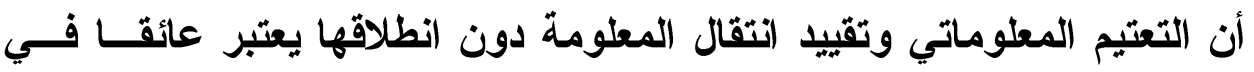
سبيل القيام بوظائف الإعلام الثقافي المرجوة كما أن خلو المضمون الفئمان الفكري من الارتباط بالهوية والتراث الفكري وبأهداف المجتمع يعمل علي اتساع مســاحة 
الاغتراب الثقافي، و يعرض مكوناتها اي الهوية إلى مضامين أخرى غريبة عن

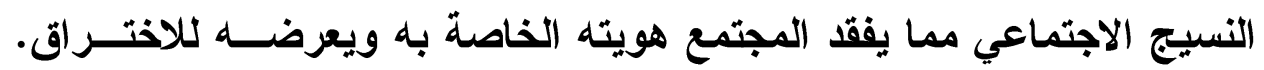

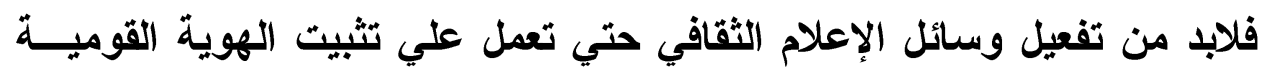

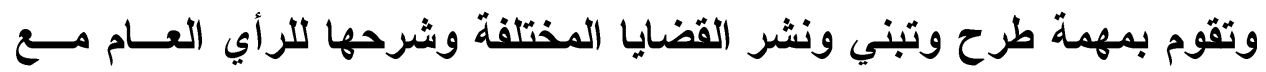
اقتراح الحلول .فوضع إستراتجيات وطنية للأعلام الثقافي وايمان متخذ ونتئن القرار بضرورة تنفيذ هذه الإستر اتيجيات يعتبر خطوة جادة لمواجهة تحديات العولمة ولمئة

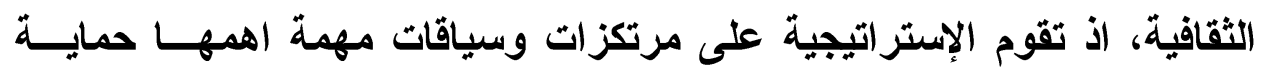

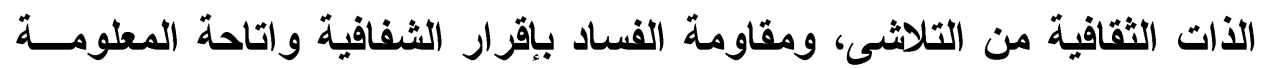

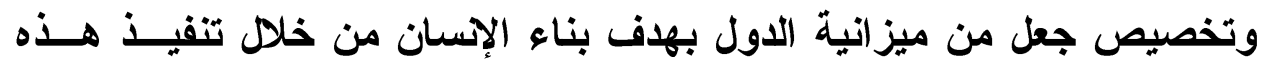
الإستراتجيات .وتقترح الاراسة توصيات من شأنها توفير بيئة صالحة للإعلام

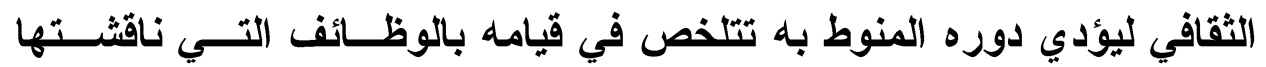

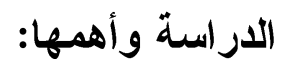

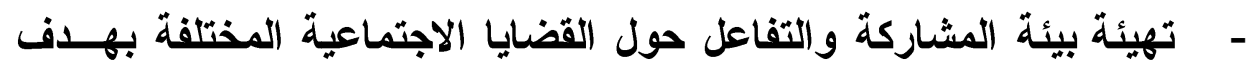
احداث التأثير الاجتماعي وتأييد قيمه ومفاهيمه المختلفة.

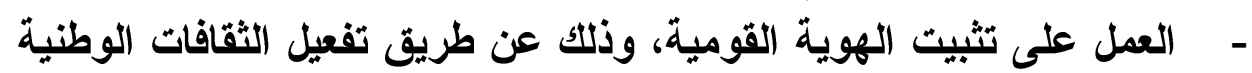
تشجيع وسائل الانتماء والمواطنة.

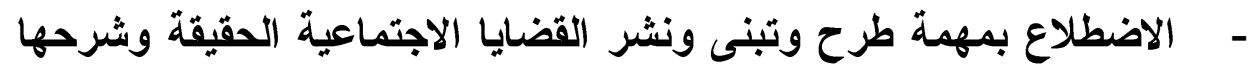

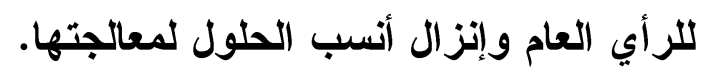

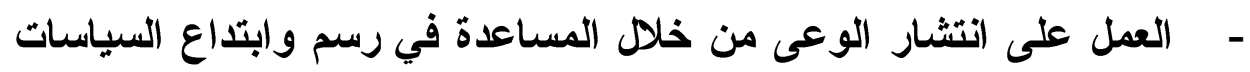

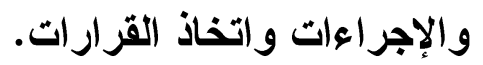

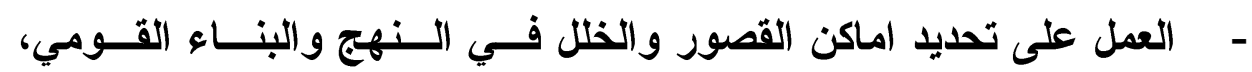

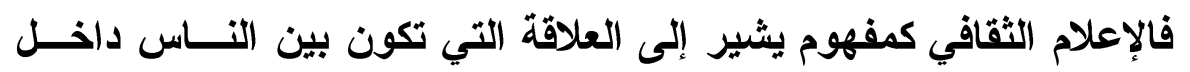

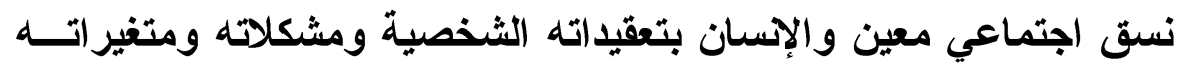

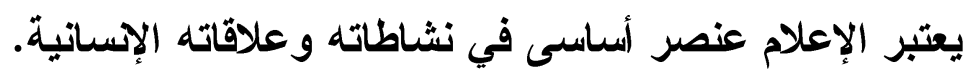

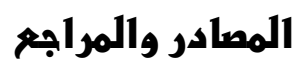

- Andrew A. Noemeka, ed , Communication for I Development, Albany, state university of New York press1994. 


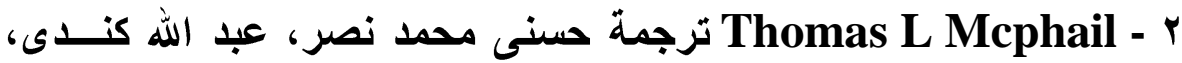

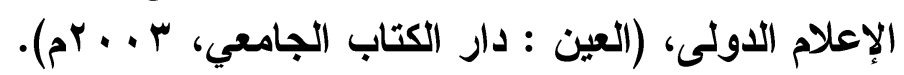

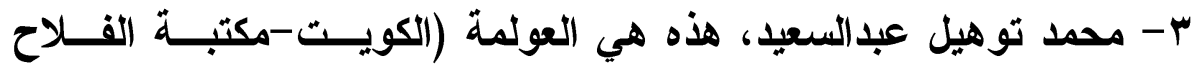

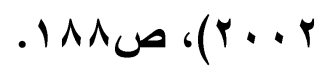

-حسن مكاوي وليلي حسين السيد، الاتصال ونظرياته المعاصــرة، الـــار

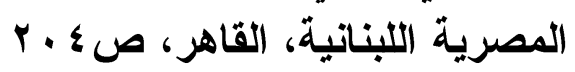

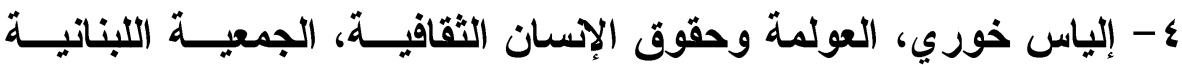

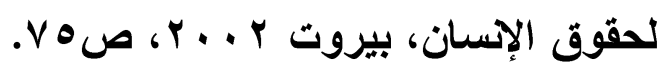

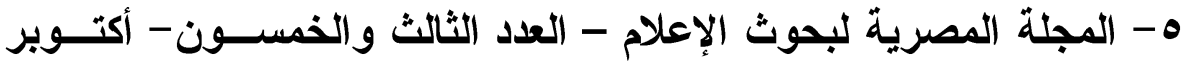

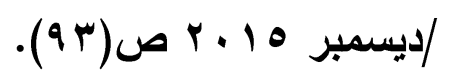

צ- مصطفي المصمودى، النظام الإعلاهي الجديد، (الكويت : عالم المعرفة،

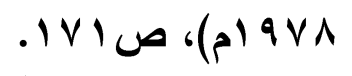

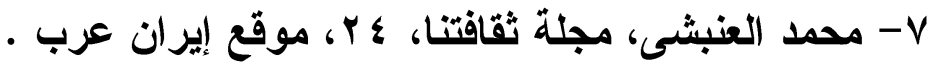

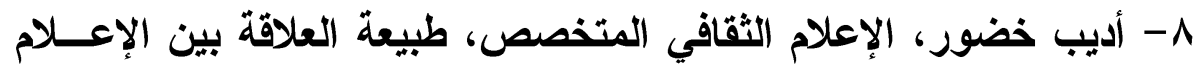

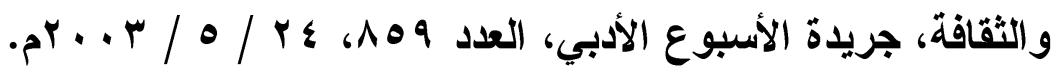

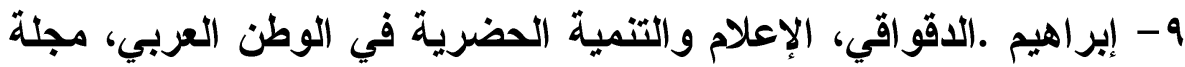

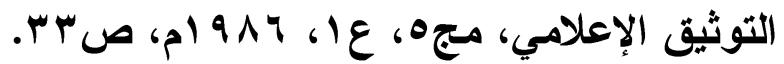
• 1 - نبيل على، قضايا عصرية، روئية معلوماتية، الهيئة المصرية للكتاب،

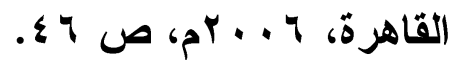
11-محمد عبدالله .مجلة الدراسات الإعلامية، العدد . . ايوليوسية سـبتمبر، المركز العربي الإقليمي للارسات الإعلامية والإعلية والسكان و التنمية والبيئة،

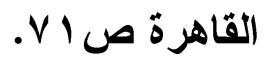
• 1 - نبيل على، قضايا عصرية، روئية معلوماتية، الهيئة المصرية للكتاب،

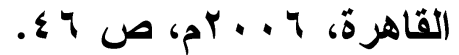
- نبيل على، قضايا عصرية، روئة مطلوماتية، الهيئة المصرية للكتاب،

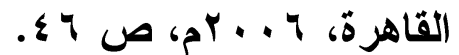
r ا - نبيل على، قضايا عصرية، روئية معلوماتية، الهيئة المصرية للكتاب،

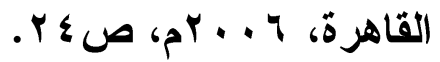


rا - شون ماكبر ايل وآخرون، أصوات متعددة وعالم واحـــ، منشــورات

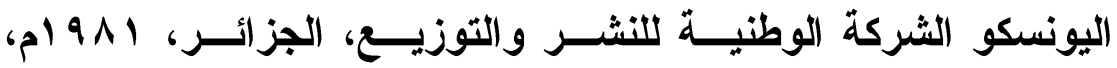
ص صroor. ع ا - بركات محمد مر اد، ظاهرة العولمة رؤية نقدية، كتاب الأمة، (الدوحة

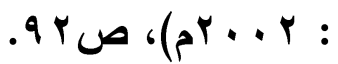

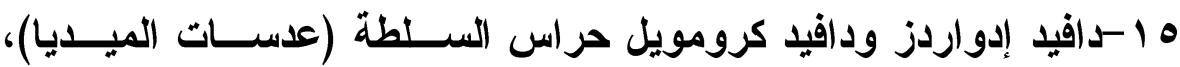

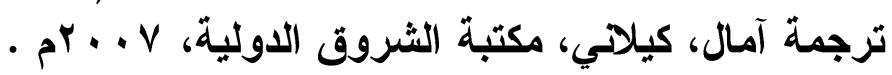

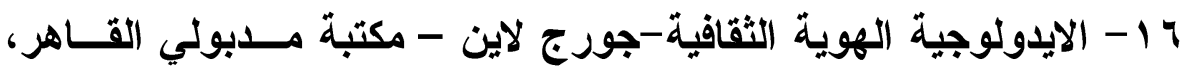
ص 99 IV -ابراهيم ابو عرقوب، الاتصال الإنساني ودوره في التفاعل الاجتماعي،

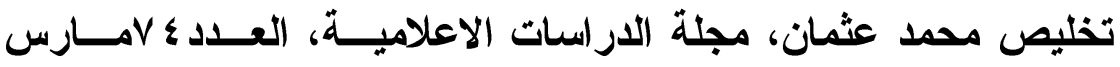
م) $99 \varepsilon$ 1 ا أ - مرجع سابق

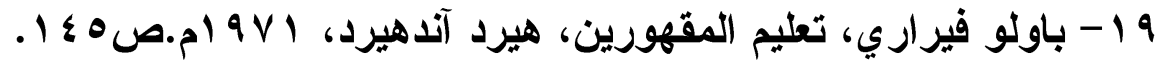

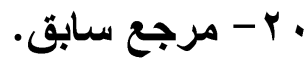

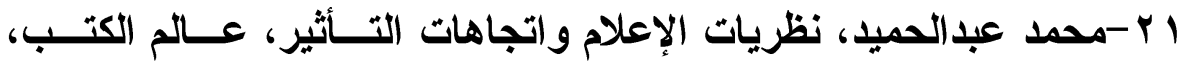

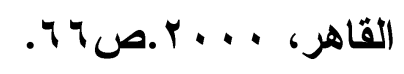

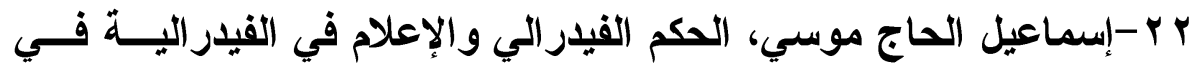

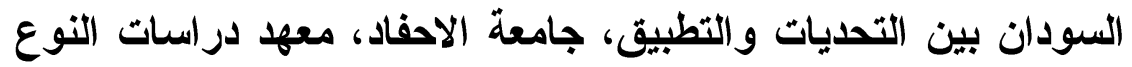

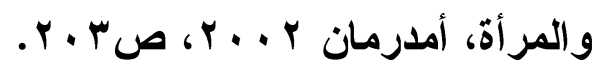

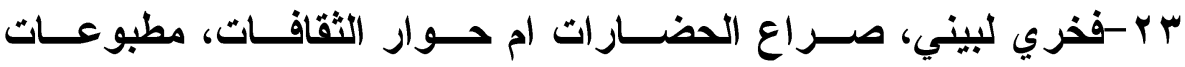

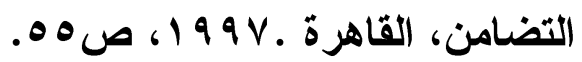
ع r - بول واني، الصراعات في السودان، مجلة محاور، مركز محمد عمر

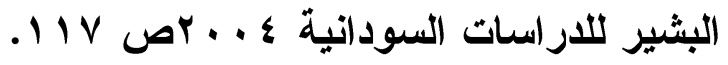

